\title{
Secular Variations of the Rainfall in Japan
}

\author{
by \\ Eiichi Suzuki \\ Meteorological Research Institute, Tokyo \\ (Received June 28, 1968)
}

\begin{abstract}
In order to study the secular variations of various rainfall amounts quantitatively, the next three methods are taken into consideration;

a. Trend inspection based on rank correlational procedure.

b. Fitting the orthogonal polynominals to secular variation.

c. Statistical quantities showing variability and persistence.

Yearly, monthly and special rainfall amounts were statistically analysed by using the electronic computer, and we obtained the following main results through geographical comparison of the statistical quantities:

(i) Over the whole area of Japan, there are more widely increasing regions than decreasing regions.

(ii) Conspicuous increasing trends can be seen at Kyūshū and Shikoku districts.

(iii) Both increasing and decreasing trends are seen disorder at Tō-hoku and Hokuriku districts, and rather apparent increasing regions in snowfall amount are scattered over these districts.

(iv) Decreasing trend can be seen at Kantō district for any kinds of rainfall amounts on the whole.

As a result, the qualitative explanations hitherto put forward by several authors have been revised quantitatively and more in detail, and some of them are more or less corrected in this paper.
\end{abstract}

\section{Introduction}

In the study of secular variations, E. BRÜCKNER (1890) must be first mentioned as a forerunner. It was he who was the first to find out the so called "BRÜCKNER periodicity" indicating the 35.5 year periodical change by use of long range records of the water level observed at the Caspian Sea.

H. Thielebein (1933) applied the method of G. Hellmann (1908) for secular variation of annual rainfall amounts in Europe, and the various contributions due to W. KÖPPEN (1928), WAGNER (1928) and ScHERHAG (1936) etc. are mostly concerned with the verification of explanation possibility for climatic secular variation based on the idea of zonal index (large scale gradient of pressure field over the northern hemisphere), in view of the general circulation. These studies however didn't deal with the secular variation of rainfall directly but were considered as quite suggestive in investigating the mechanism of rainfall variation generally.

H.C. WILleT (1950) tried to explain the various periodicities noticed in secular 
rainfall variations by annual change of both low index type and high-index type specified by the meteorological character of the general circulation, but consideration of geographical conditions was not always adequate in his study. On the other hand, in Japan, T. YАмамото (1950) studied the long range variation of rainfall in the Far Eastern Asia mainly based on the collected reports of the older rainfall data at Keijo collected by Y. WADA (1907).

M. OGawara, T. Ozawa, E. Suzuki, T. Fujita and K. Tomatsu (1952) investigated somewhat systematically on the climatic variation since the commencement of routine observation (from 1900 to 1950) by use of several modern statistical procedures and the present author taking charge of statistical study of rainfall variations, and verifing the secular variations of monthly rainfall amounts at Sapporo, Tokyo and Fukuoka in January and August mainly by use of five year and ten year simple averages and orthogonal polynomials fitting to these averaged variations. However the author's results gained in this collaborative research (1952) are now considered inadequate in view of both the number of stations and the period observed.

H. ARAKAWA (1958) studied climatic variation based on the posthumous work of S. FUJIWHARA (1955) which he edited and sent to the world, but his study is hardly concerned with the secular variation within our period. K. TAKAHASHI (1956) took up several periodicities supposedly presented in secular variations of monthly amounts at representative points (Tokyo, Matsumoto and Niigata etc.) by use of periodgram analysis, but scarcely any permanently stable periodicities were found out after all, except 11 and 35.5- year periodic cycles.

Even if the numerous results he gained concerning periodicity are certainly suggestive for seasonal forecasting of climatic rainfall amount, they are not so for describing secular variation in reference to possible causes of climatic rainfall change.

Both the author (1957) and I. MORI (1959) independently discussed the secular variations of annual rainfalls caused by Bai-u and typhoon, and the former using the two statistical methods (rank correlation method and moving average) and the latter taking only a subjective view of diagrammatic secular variation at several points of Japan.

In these two studies, the data collected were not sufficient because only ten or so points came into consideratien up till the year 1954. A reconsideration of the problem is now in order on the basis of recent data at as many observation points as possible.

Recently, T. SEKiguchi (1964) reported the systematic results of trend analysis on annual rainfall amounts in Japan by "Residual Mass Curve," and his study is quite suggestive to the present author as will be seen later. The author's approach is somewhat different from the various methods mentioned above in making use of the modern statistical method, and in taking into account the longest period and as many observation points as possible.

The numerous foregoing studies of secular variations of rainfall amounts may be summarized in the following condensed statement:

"Many statistical approaches to the study of secular variation have been developed such as successive variation ratio or width of fluctuation (der Quotient und die Weite 
der Schwankung in German), moving or simple average, periodgram analysis, residual mass curve analysis, rank correlation method and polynomial fitting will be listed up here, and as a result, periodicities of 89-year (EASTON), 35.5-year (BRÜCKNER), 11-year (the same to the case of sun-spot number fluctuation), about 9-year (this periodicity is often noticed in secular variation of the high pressure zonal belt in middle latitudes), about 4-year (not yet known in relation to the other phenomena) etc. have been taken up and examined in detail and various tendencies (increasing, persistent and decreasing trends) have been locally verified and conjecturally explained."

In this paper, on the contrary, the author first proposes a rank corrrelation method which makes it possible to examine the statistically significant trend of the general tendency contained in secular variation, and secondly supplements the orthogonal or ordinary polynomial fitting to actual secular variation in order to clarify the cyclic up-and-down tendency in a wide sense. Moreover, several useful statistical quantities that can explain persistency or variation scale of secular variation are taken into account to complement the results obtained by the above two methods.

According to H. ARAKAWA (1955), periodgram analysis is not always suitable to analyse the irregular cyclic variation contained in actual secular variation of various rainfall amounts, so the author tried to fit several polynomials of the first, 2nd, 3rd and 4 th orders, in order to clarify the cyclic character and to find out the time periods showing the maximum and the minimum year within the total range of observed periods.

The synthetic descriptions of trend characters are given after three such individual analyse to actual secular variations. From the necessity of obtaining as much stable result as possible, the author used the longest possible period (from the commencement year to the year of 1963 or 1964) for the 56 representative points as has often been done in the chapters of the author's previous paper (1967).

However, for convenience sake of geographical comparison, the range of observation period was adjusted to the longest commonly possible period between 1900 and 1963 (or 1964).

On the other hand, as regards the amount of rain caused by typhoons, the range had to be cut down to the period 1924-1964 in order to maintain the substantial homogeneity of data.

\section{Statistical methods applied to the study of secular variation}

\section{(i) Trend inspection based on rank correlational procedure}

Let $x_{1}, x_{2}, x_{3}, \cdots, x_{N-1}, x_{N}$ be time series of successive rainfall amount obtained year by year, $x_{1}$ being the rainfall amount of the commencement year, $x_{2}$ that of the next year, $\cdots, x_{N}$ that of the most recent year respectively, and let $n_{i}(i=1,2, \cdots, N)$ be such a number showing the occurrence frequency of rainfall amounts which is greater than $x_{i}$ behind the $i$-th value $x_{i}$ in such a time series, then evidently, the next relations can be satisfied,

$$
N-i \geqq n_{i} \geqq 0 \quad\left(n_{N-1}=1 \text { or } 0, n_{N}=0\right)
$$

and the summation of $n_{i}, P \equiv \sum_{i=1}^{N-1} n_{i}$ is a fundamental measure to denote the general situation of the secular trend in the following sense: 
If the secular trend is monotone increase, then the inequality relations

$$
x_{1}<x_{2}<x_{3}<\cdots<x_{N-1}<x_{N}
$$

is evidently satisfied and so we have

$$
\begin{gathered}
n_{i}=N-1, n_{2}=N-2, \cdots, n_{i}=N-i, \cdots, n_{N-1}=1 \\
P \equiv \sum_{i=1}^{N-1} n_{i}=N(N-1) / 2
\end{gathered}
$$

If the secular trend is monotone decrease on the contrary, then the opposite inequality relation shown by

$$
x_{1}>x_{2}>x_{3}>\cdots>x_{N-1}>x_{N}
$$

is also evidently satisfied and so we have

$$
\begin{gathered}
n_{1}=0, n_{2}=0, \cdots, n_{i}=0, \cdots, n_{N-1}=0, n_{N}=0 \\
P \equiv \sum_{i=1}^{N-1} n_{i}=0
\end{gathered}
$$

Consequently, the values of $P$ are to be presented within the range $N(N-1) / 2 \sim 0$.

Therefore, if we consider the modified measure $S$ defined by

$$
S=2 P-N(N-1) / 2
$$

then the next correspondence relations are gained for a large number $N$

$$
\begin{array}{ll}
S=N(N-1) / 2 \gg 0 & \text { for the completely monotone increasing trend } \\
S=-N(N-1) / 2 \ll 0 & \text { for the completely monotone decreasing trend }
\end{array}
$$

And moreover, $S$ is close to 0 when the time series $\left\{x_{1}, x_{2}, \cdots, x_{N-1}, x_{N}\right\}$ is a random arrangement series having no increasing or decreasing trend. According to the statistical theory concerning to order statistics, as has been well known to the statistician, the quantity

$$
I_{T}=S / \sqrt{N(N-1)(2 N+5) / 18}
$$

is distributed approximately following the normal distribution with mean 0 and standard deviation 1 for a large number $N$ under the assumption that the time series $\left\{x_{1}\right.$, $\left.x_{2}, \cdots, x_{N}\right\}$ is randomly arranged as was mentioned above. Accordingly, the author termed the quantity $I_{T}$ as "trend index" to express the general tendency of secular variation, and assumed the next judgment criterions to denote quantitatively the non parametric trend:

$$
\begin{array}{cl}
I_{T} \geqq 2 & \text { Conspicuous increasing trend (about 2\% level) } \\
2>I_{T} \geqq 1 & \text { Significant increasing trend (about 15\% level) } \\
1>I_{T}>0 & \text { Not significant but increasing trend } \\
0>I_{T}>-1 & \text { Not significant but decreasing trend } \\
-1 \geqq I_{T}>-2 & \text { Significant decreasing trend (about 15\% level) } \\
-2 \geqq I_{T} & \text { Conspicuous decreasing trend (about } 2 \% \text { level) }
\end{array}
$$

For example, in the case of $2>I_{T} \geqq 1$, the hypothesis of random arrangement is rejected at about 15\% level of significance and the increasing trend is suggested with a rather large reliability. The analogous judgment holds for other cases of $I_{T}$ as a rule. 
(ii) Fitting several polynomials to secular variation

Let $x_{1}, x_{2}, \cdots, x_{N}$ be a time series of size $N$ as in (i), and let the polynomial of the $p$ th order $(p=1,2,3$ and 4$)$ to be fitted to this time series be

$$
x_{t}=a_{0}+a_{1} \xi_{1}(t)+a_{2} \xi_{2}(t)+\cdots+a_{p} \xi_{p}(t) \quad \text { (orthogonal polynomial) }
$$

where $p \ll N$, then orthogonal coefficients $\left(a_{0}, a_{1}, a_{2}, \cdots, a_{p}\right)$ can be generally determined by normal regression theory of modern statistics, and the ordinary coefficients $\left(b_{0}, b_{1}\right.$, $\left.b_{2}, \cdots, b_{p}\right)$ are also derived easily from the set $\left(a_{0}, a_{1}, a_{2}, \cdots, a_{p}\right)$, and these ordinary coefficients $\left(b_{0}, b_{1}, b_{2}, \cdots, b_{p}\right)$ are completely the same as the results obtained by the least square method. Hereafter, the author will describe the computational procedure only as follows: In order to fit the orthogonal polynomial of the $p$ th order, the author must pick up the value of $\xi_{i \alpha}(i=1,2, \cdots, p ; \alpha=1,2, \cdots, N)$ for the given numbers $p$ and $N$ from a previously provided table, such as the one seen on p. 237 of the "Statistical Table" (New edition): published by Kawade Shobō (1952). And from combining the series $\left\{\xi_{i_{\alpha}}\right\}$ and time series $\left\{x_{\alpha}\right\}(\alpha=1,2, \cdots, N)$, the following statistical quantities can be easily computed.

$$
\left.\begin{array}{c}
a_{i j}=\sum_{\alpha=1}^{N} \xi_{i \alpha} \xi_{j \alpha}, a_{0 i}=\sum_{\alpha=1}^{N} x_{\alpha} \xi_{i \alpha}, a_{00}=\sum_{\alpha=1}^{N} x_{\alpha}{ }^{2} \\
(i, j=1,2, \cdots, p)
\end{array}\right\}
$$

Moreover, from the inverse $p \times p$ symmetric matrix $\left[a^{i j}\right]=\left[a_{i j}\right]^{-1}$ we have the following necessary orthogonal coefficients after all:

$$
a_{0}=\frac{1}{N} \sum_{\alpha=1}^{N} x_{\alpha}=\bar{x}, \quad a_{i}=\sum_{j=1}^{p} a^{i j} a_{0 j}(i=1,2, \cdots, p)
$$

To verify the fitness extent of this polynomial, the quantity essentially equivalent to the residual sum of square

$$
\chi_{N-p-1}^{2} \equiv N \sum_{\alpha=1}^{N}\left\{x_{\alpha}-a_{0}-\sum_{i=1}^{p} a_{i} \xi_{i \alpha}\right\}^{2} / \sum_{\alpha=1}^{N}\left(x_{\alpha}-\bar{x}\right)^{2}
$$

is computed and the quantity $\chi_{N-p-1}^{2}$ is distributed as $\chi^{2}$-distribution with the degree of freedom $N-p-1$, so statistical significance can be tested by such $\chi^{2}$-distribution table as is well known to the statistician, and at the same time, the significance test of each orthogonal coefficient $a_{i}(i=1,2, \cdots, p)$ is also similarly tested by changing the degree of freedom only.

In this case, the significant coefficient means that it is significantly different from 0 on each specified level of significance. Nextly, to have ordinary coefficients $\left(b_{0}, b_{1}, b_{2}, \cdots, b_{p}\right)$ from the gained orthogonal coefficients the following well-known correspondence relations between them will be used

$$
\begin{aligned}
& \xi_{1}=t-\bar{t} \\
& \xi_{2}=(t-\bar{t})^{2}-\left(N^{2}-1\right) / 12 \\
& \xi_{3}=(t-\bar{t})^{3}-\left(3 N^{2}-7\right)(t-\bar{t}) / 20 \\
& \xi_{4}=(t-\bar{t})^{4}+\left(3 N^{2}-13\right)(t-\bar{t})^{2} / 14+3\left(N^{2}-1\right)\left(N^{2}-9\right) / 560
\end{aligned}
$$

where

$$
\bar{t}=\sum_{\alpha=1}^{N} \alpha / N=(N+1) / 2
$$


These correspondence relations are also given on p. 238-239 of the "Statistical Table" (New edition): published by Kawade Shobō (1952) And in this paper, the cases $p=1$, 2,3 and 4 are computed.

\section{(iii) Statistical quantities showing variability and persistence}

Among the various statistical quantities given in the authors previous paper (1967), mean difference M.D. $(y)$ of annual rainfall amounts is the mean value of the possible absolute differences between any two values of annual rainfall amounts within a given time series $\left(x_{1}, x_{2}, \cdots, x_{N}\right)$ and is defined by $\sum_{j=1}^{N} \sum_{i=1}^{N}\left|x_{i}-x_{j}\right| / N(N-1)$. And Gini's concentration coefficient G.C. $(y)$ of annual rainfall amounts is apparently a measure of relative variability to the mean square as is expressed by G.C. $(y)=$ M.D. $(y) / \bar{y}^{2}$. So both M.D. $(y)$ and G.C. $(y)$ are considered as statistical quantities denoting variability of secular variation.

And, Goutereau ratio G. $(y)$ is a mean ratio of absolute successive difference to absolute difference from mean value and is defined by

$$
N \sum_{i=1}^{N-1}\left|x_{i+1}-x_{i}\right| /(N-1) \sum_{i=1}^{N}\left|x_{i}-\bar{x}\right| \sim \sum\left|x_{i+1}-x_{i}\right| / \Sigma\left|x_{i}-\bar{x}\right|
$$

And so G. $(y)$ shows a certain relative persistency and both positive and negative persistencies can be determined by knowing whether computed G. $(y)$ is smaller or larger than $\sqrt{2}$, and absolute durability A.D. $(y)$ is an expected value of absolute successive difference $\sum_{i=1}^{N-1}\left|x_{i+1}-x_{i}\right| /(N-1)$. So both Goutereau ratio G. $(y)$ and A.D. $(y)$ are considered as statistical quantities denoting the persistency of secular variation.

In the following section, computed results are shown for several cases.

\section{Secular variation in annual rainfall amounts}

The representative secular variations of annual rainfall amounts are graphically shown for Fukuoka, Tokyo and Sapporo in Fig. 1 as the examples. In this figure, the period marked by $*$ means the significantly larger period of five or ten years than the standard initial period of 1901-1905 or 1901-1910 at 5\% level, and the period marked by $\Delta$ means the significantly smaller period of five or ten years in the same sense.

For convenience of geographical comparison, the author adopted the unified period 1900-1963 $(N=64)$ uniformly for all possible points, to compute trend index $I_{T}$.

Fig. 2 shows geographical distribution of $I_{r}$ for annual rainfall amounts, and we have the next outline from this figure:

Number of points satisfying the inequality $I_{T}>0 \cdots \cdots 33$

Number of points satisfying the equality $I_{T}=0 \cdots \cdots 1$

Number of points satisfying the inequality $I_{T}<0 \cdots \cdots 22$

And so, the number of increasing points is somewhat larger than that of decreasing points in Japan. In regional classification based on increasing and decreasing trends, the following results can be gained by Fig. 2:

Districts of increasing annual rainfall amounts-Kyushū, Chūgoku, Hokuriku, Tōhoku (Japan Sea side) and Hokkaidō.

Districts of decreasing annual rainfall amounts-Shikoku, Tōkai, Kantō and Tōhoku (Pacific Ocean side). 

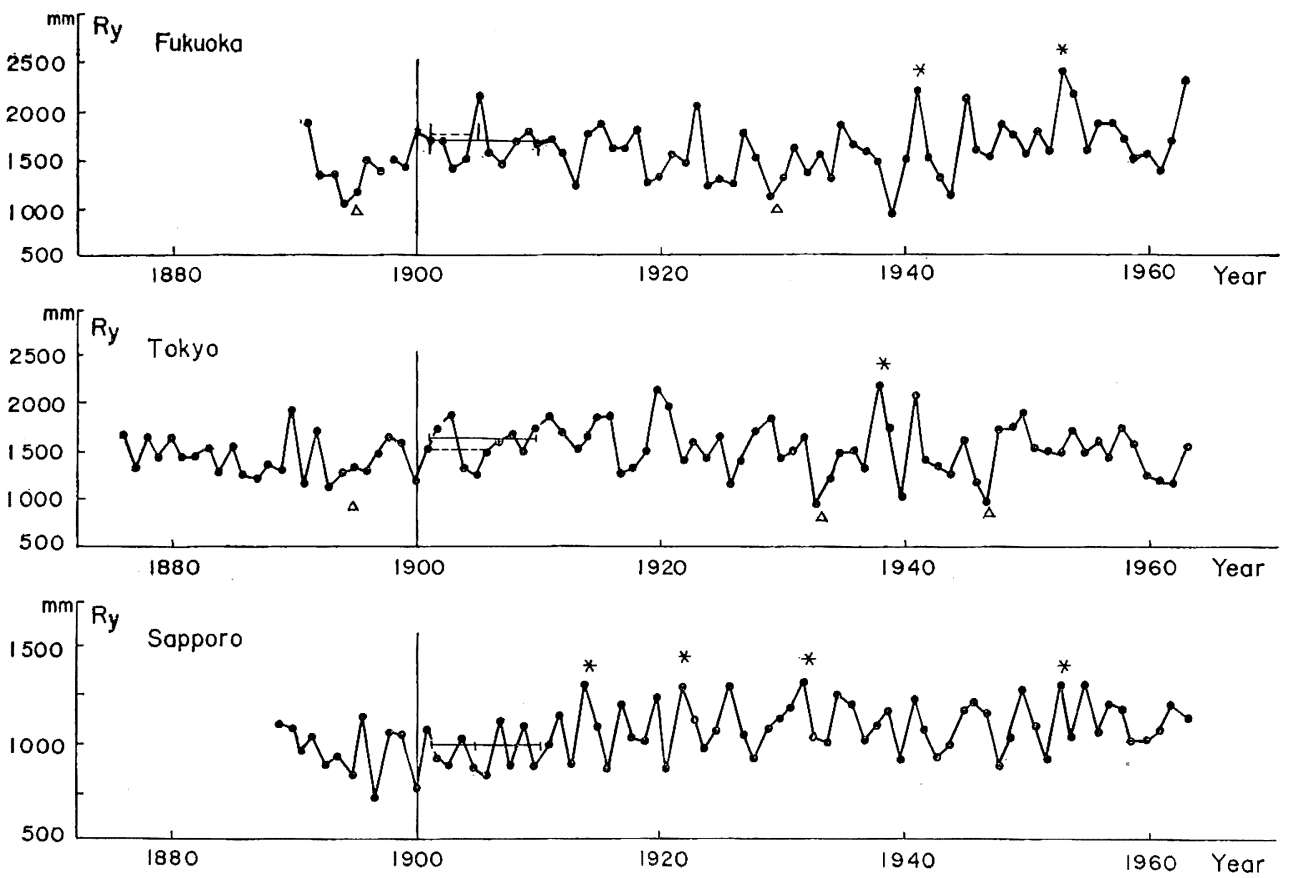

Fig. 1. Secular variations of annual rainfall amounts $R_{y}$ at the three representative points in Japan.

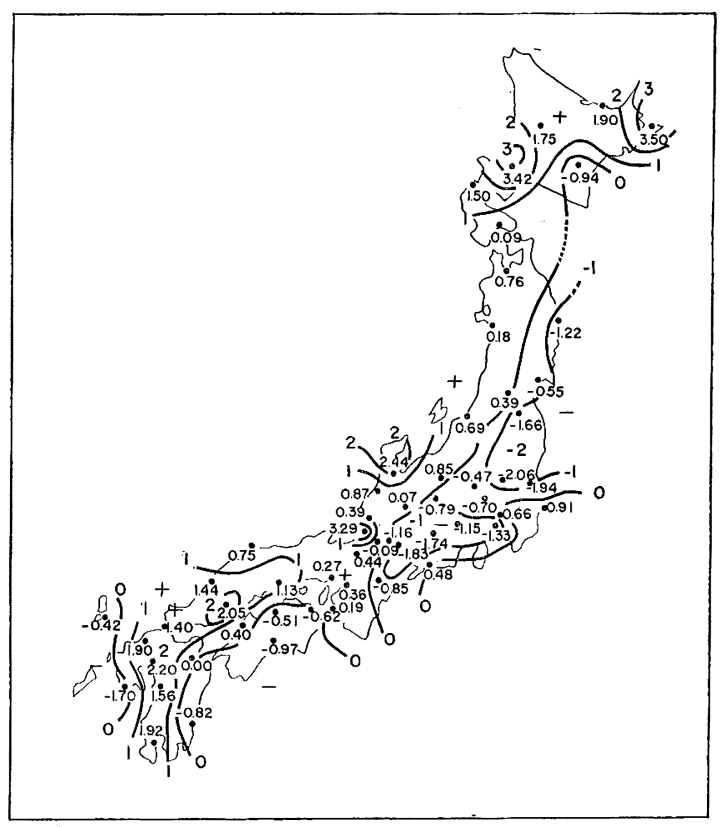

Fig. 2. Geographical distribution of trend index $I_{T}$ for annual rainfall amounts in Japan. 
And among these districts, the central part of Kyush $\bar{u}$, the northern Hokuriku district and Hokkaido have significant increasing tendencies, while the northern Kanto district and the Pacific Ocean side of the Tōhoku district have significant decreasing tendencies. T. SEKIGUCHI (1964) considered that one extraordinary year with special heavy or light annual rainfall carries so much weight in the methods customarily used in the past (i. e. moving average, comparison of mean values between two different periods, etc.), that the real secular trends is liable to be hidden away from our eye. This induced him to use the method of Residual Mass Curve. The present writer generally concurs with SEKIGUCHI's point of view, but it must be pointed out the

Table 1 (a). Fitting results of several polynomials to the secular variations of annual rainfall amounts. $b_{0}$ is constant and $b_{i}(i=1,2,3,4)$ is coefficient estimated by maximum likelihood method.

\begin{tabular}{|c|c|c|c|c|c|c|}
\hline \multirow{2}{*}{ polynomial type } & \multirow{2}{*}{$\begin{array}{l}\text { Mean } \\
(\mathrm{mm})\end{array}$} & \multicolumn{2}{|c|}{ 1st order } & \multicolumn{3}{|c|}{ 2nd order } \\
\hline & & $b_{0}$ & $b_{1}$ & $b_{0}$ & $b_{1}$ & $b_{2}$ \\
\hline Kagoshima & 2294.7 & 2211.74 & $2.677 *$ & 2503.9 & $-26.068 *$ & $0.464^{*}$ \\
\hline Miyazaki & 2571.6 & 2530.84 & 1.314 & 2585.6 & -4.076 & 0.087 \\
\hline Kumamoto & 1869.6 & 1854.75 & 0.479 & 2111.0 & $-24.732^{*}$ & $0.407^{*}$ \\
\hline Nagasaki & 1985.5 & 1953.38 & 1.037 & 1989.0 & -2.472 & 0.057 \\
\hline Izuhara & 2220.1 & 2303.29 & $-2.683^{*}$ & 2437.7 & -15.906 & 0.213 \\
\hline Saga & 1854.0 & 1757.98 & $3.098 * *$ & 1908.2 & -11.675 & 0.238 \\
\hline Fukuoka & 1660.5 & 1606.41 & 1.745 & 1750.0 & -12.380 & 0.228 \\
\hline Ōita & 1664.4 & 1647.89 & 0.532 & 1790.7 & -13.521 & 0.226 \\
\hline Shimonoseki & 1689.4 & 1664.38 & 0.808 & 1773.7 & -9.945 & 0.173 \\
\hline Kōchi & 2650.3 & 2674.26 & -0.771 & 2832.2 & -16.306 & 0.251 \\
\hline Tokushima & 1663.1 & 1681.53 & -0.595 & 1853.5 & -17.510 & 0.273 \\
\hline Tadotsu & 1144.8 & 1172.13 & -0.881 & 1203.5 & -3.969 & 0.050 \\
\hline Matsuyama & 1370.9 & 1414.31 & -1.400 & 1470.8 & -7.349 & 0.096 \\
\hline Hiroshima & 1567.6 & 1510.99 & 1.827 & 1616.3 & -8.527 & 0.167 \\
\hline Okayama & 1129.1 & 1029.75 & 1.172 & 1168.9 & -6.326 & 0.121 \\
\hline Hamada & 1667.1 & 1558.26 & $3.511 * *$ & 1618.1 & -2.377 & 0.095 \\
\hline Sakai & 1970.8 & 1927.08 & 1.411 & 1973.0 & -3.105 & 0.073 \\
\hline Kōbe & 1340.4 & 1309.74 & 0.987 & 1386.9 & -6.598 & 0.122 \\
\hline Ōsaka & 1353.5 & 1347.88 & 0.181 & 1495.6 & -14.351 & 0.234 \\
\hline Wakayama & 1497.5 & 1518.78 & -0.687 & 1699.7 & $-18.485^{*}$ & 0.287 \\
\hline Kyōto & 1572.2 & 1536.81 & 1.143 & 1729.6 & -17.820 & $0.306^{*}$ \\
\hline Hikone & 1677.7 & 1642.02 & 1.153 & 1843.6 & $-18.683^{*}$ & $0.320 *$ \\
\hline Tsu & 1757.9 & 1823.68 & -2.122 & 1951.7 & -14.716 & 0.203 \\
\hline Nagoya & 1602.6 & 1715.88 & $-3.654 * *$ & 1855.8 & -17.418 & 0.222 \\
\hline Gifu & 1917.4 & 2008.18 & $-2.930^{*}$ & 2219.5 & $-23.714^{*}$ & $0.335^{*}$ \\
\hline Takayama & 1799.8 & 1822.78 & -0.741 & 1928.6 & -11.154 & 0.168 \\
\hline Hamamatsu & 1963.5 & 2043.81 & $-2.592^{*}$ & 2154.3 & -13.464 & 0.175 \\
\hline Yokohama & 1687.1 & 1749.82 & -2.024 & 1720.8 & 0.831 & -0.046 \\
\hline
\end{tabular}

Remark :

$*$,** show the significant coefficients at $5 \%$ and $1 \%$ levels of significance respectively. 
above effect is not completely eliminated in the residual mass curve since the annual rainfall ratio to the normal mean value is also utilized in this procedure.

In the rank correlation method used by the author in this paper, the special heavy or light annual rainfalls have no influence in the computation of trend index $I_{T}$ since annual values themselves are not taken into account but their ordered rankings only are considered in the computation of $I_{T}$. Thus the disturbing effect mentioned by $\mathrm{T}$. SEKIGUCHI is considered to be completely eliminated in trend anlysis of secular variation. (For instance, the same results are attainable in any cases whether the

Table 1 (b). Fitting results of several polynomials to the secular variations of annual rainfall amounts. $b_{0}$ is constant and $b_{i}(i=1,2,3,4)$ is coefficient estimated by maximum likelihood method.

\begin{tabular}{|c|c|c|c|c|c|c|}
\hline \multirow{2}{*}{$\begin{array}{l}\text { polynomial type } \\
\text { Station }\end{array}$} & \multirow{2}{*}{$\begin{array}{l}\text { Mean } \\
(\mathrm{mm})\end{array}$} & \multicolumn{2}{|c|}{ 1st order } & \multicolumn{3}{|c|}{ 2nd order } \\
\hline & & $b_{0}$ & $b_{1}$ & $b_{0}$ & $b_{1}$ & $b_{2}$ \\
\hline Tokyo & 1583.7 & 1642.85 & -1.908 & 1587.7 & 3.515 & -0.087 \\
\hline Chöshi & 1713.5 & 1687.52 & 0.839 & 1716.9 & -2.055 & 0.047 \\
\hline Mito & 1438.7 & 1500.24 & -1.983 & 1484.4 & -0.423 & -0.025 \\
\hline Utsunomiya & 1538.8 & 1652.84 & $-3.678 * *$ & 1634.1 & -1.833 & -0.030 \\
\hline Maebashi & 1273.3 & 1310.70 & -1.205 & 1338.1 & -3.897 & 0.043 \\
\hline Kumagaya & 1310.7 & 1336.86 & -0.843 & 1358.3 & -2.950 & 0.034 \\
\hline Köfu & 1234.3 & 1259.58 & -0.816 & 1266.9 & -1.537 & 0.012 \\
\hline Nagano & 1002.9 & 997.28 & 0.181 & 1040.8 & -4.092 & 0.069 \\
\hline Matsumoto & 1083.4 & 1136.98 & -1.726 & 1223.9 & -10.281 & 0.138 \\
\hline Iida & 1668.6 & 1740.17 & -2.307 & 1959.9 & $-23.921^{*}$ & $0.349^{*}$ \\
\hline Tsuruga & 2404.3 & 2205.86 & $6.401^{* *}$ & 2202.7 & 6.717 & -0.005 \\
\hline Fukui & 2414.5 & 2371.52 & 1.387 & 2462.7 & -7.575 & 0.144 \\
\hline Kanazawa & 2569.1 & 2543.46 & 0.828 & 2741.7 & $-18.671^{*}$ & $0.314^{*}$ \\
\hline Fushiki & 2261.3 & 2184.70 & 2.470 & 2310.7 & -9.927 & 0.200 \\
\hline Niigata & 1805.1 & 1804.18 & 0.030 & 1948.4 & -14.160 & 0.229 \\
\hline Fukushima & 1181.9 & 1222.86 & -1.320 & 1226.9 & -1.719 & 0.006 \\
\hline Ishinomaki & 1121.6 & 1140.21 & -0.602 & 1170.8 & -3.612 & 0.049 \\
\hline Miyako & 1324.8 & 1387.06 & -2.010 & 1468.1 & -9.978 & 0.129 \\
\hline Yamagata & 1233.3 & 1223.75 & 0.309 & 1196.8 & 2.957 & -0.043 \\
\hline Akita & 1805.5 & 1811.63 & -0.198 & 1861.4 & -5.097 & 0.079 \\
\hline Aomori & 1401.2 & 1394.56 & 0.213 & 1333.2 & 6.250 & -0.097 \\
\hline Hakodate & 1167.9 & 1176.14 & -0.265 & 1079.5 & 9.243 & -0.153 \\
\hline Obihiro & 941.4 & 946.48 & -0.163 & 917.5 & 2.684 & -0.046 \\
\hline Suttsu & 1252.7 & 1180.03 & 2.344 & 1056.7 & 14.475 & -0.196 \\
\hline Sapporo & 1094.4 & 1004.00 & $2.915 *$ & 947.1 & 8.507 & -0.090 \\
\hline Asahikawa & 1109.7 & 1039.96 & 2.250 & 1026.8 & 3.541 & -0.021 \\
\hline Abashiri & 847.5 & 833.60 & 0.450 & 750.1 & 8.662 & -0.132 \\
\hline Nemuro & 1028.9 & 920.46 & $3.500^{* * *}$ & 872.5 & 8.212 & -0.076 \\
\hline
\end{tabular}

Remark :

*, ** show the significant coefficients at $5 \%$ and $1 \%$ levels of significance respectively. 
largest value of rainfall amount is quite much or slightly larger than the secondary value of rainfall amount in a given time series of secular annual rainfall amounts).

On the other hand, the rank correlation method has the following merits and demerits in actual application.

Merits-Each year has equal weight and $I_{T}$ can be computed independent of the original value itself and the original frequency distribution of time series, and can be tested statistically for the significant or non-significant trend of secular variation.

Table 1 (c). Fitting results of several polynomials to the secular variations of annual rainfall amounts. $b_{0}$ is constant and $b_{i}(i=1,2,3,4)$ is coefficient estimated by maximum likelihood method.

\begin{tabular}{|c|c|c|c|c|c|c|c|c|c|}
\hline polynomial & & 3rd or & rder & & & & 4th order & & \\
\hline Station & $b_{0}$ & $b_{1}$ & $b_{2}$ & $b_{3}$ & $b_{0}$ & $b_{1}$ & $b_{2}$ & $b_{3}$ & $b_{4}$ \\
\hline Kagoshima & 2621.0 & $-49.66 * *$ & $1.421 *$ & -0.010 & 2252.3 & $78.51 * *$ & $-8.056 *$ & $0.229 *$ & -0.0019 \\
\hline Miyazaki & 2669.0 & -20.89 & 0.711 & -0.007 & 2459.8 & 51.84 & -4.608 & 0.128 & -0.0011 \\
\hline Kumamoto & 2139.9 & $-30.56^{*}$ & 0.643 & -0.003 & 1991.9 & 20.92 & -3.164 & 0.094 & -0.0008 \\
\hline Nagasaki & 1941.4 & 7.142 & -0.334 & 0.004 & 1795.1 & $57.99 *$ & -4.095 & 0.099 & -0.0008 \\
\hline Izuhara & 2244.7 & $23.01 *$ & $-1.368 *$ & 0.017 & 2171.5 & 48.46 & -3.251 & 0.064 & -0.0004 \\
\hline Saga & 1902.0 & -10.43 & 0.189 & 0.001 & 1777.5 & 32.86 & -3.014 & 0.081 & -0.0007 \\
\hline Fukuoka & 1821.8 & $-26.87 *$ & 0.816 & -0.006 & 1637.9 & 37.11 & -3.914 & 0.113 & -0.0010 \\
\hline Ōita & 1840.6 & $-23.56^{*}$ & 0.634 & -0.004 & 1652.7 & 41.74 & -4.195 & 0.117 & -0.0010 \\
\hline Shimonoseki & & -10.47 & 0.194 & -0.000 & 1549.8 & $68.28^{*}$ & $-5.629 *$ & 0.147 & -0.0 \\
\hline Kōchi & 2920.0 & $-34.01 * *$ & 0.970 & -0.008 & 2794.1 & 9.781 & -2.268 & 0.074 & 007 \\
\hline Tokushima & & -11.11 & & & & $56.22^{*}$ & -4.967 & & -0.0010 \\
\hline Tadotsu & 1200.6 & -3.378 & 0.025 & 0.000 & 1112.8 & 27.13 & -2.230 & 0.057 & -0.0005 \\
\hline Matsuyama & 1573.5 & $-27.27^{*}$ & 0.905 & -0.009 & 1435.4 & 20.78 & -2.647 & & -0.0004 \\
\hline Hiroshima & & -13.07 & 0.351 & -0.002 & 1472.5 & 44.75 & -3.925 & 0.106 & -0.0009 \\
\hline Okayama & 1184.7 & -9.498 & 0.250 & -0.001 & 1075.5 & 28.48 & -2.559 & 0.069 & -0 . \\
\hline Hamada & 1496.7 & -22.10 & -0.900 & 0.010 & 1418.5 & 49.32 & -2.912 & 0.061 & -0.0004 \\
\hline Sakai & 1897.4 & 12.14 & -0.547 & 0.007 & 1843.0 & 31.04 & -1.945 & 0.042 & -0.0003 \\
\hline Köbe & 1324.5 & 5.970 & -0.389 & 0.005 & 1265.6 & 26.45 & -1.903 & 0.044 & -0.0003 \\
\hline Ōsaka & 1453.1 & -5.778 & -0.114 & 0.004 & 1366.3 & 24.41 & -2.347 & 0.060 & -0.0005 \\
\hline Wakayama & 1699.1 & -18.35 & 0.282 & 0.000 & 1538.7 & 37.40 & -3.842 & 0.104 & -0.0008 \\
\hline Kyōto & 1670.2 & -5.832 & -0.181 & 0.005 & 1532.4 & & -3.723 & & -0.0007 \\
\hline Hikone & 1719.7 & 6.329 & -0.696 & 0.010 & 1669.5 & 23.75 & -1.985 & 0.043 & -0.0003 \\
\hline Tsu & 1868.1 & 2.142 & -0.482 & 0.007 & 1758.5 & 40.25 & -3.301 & 0.078 & 0.0006 \\
\hline Nagoya & 1833.2 & -12.86 & 0.036 & 0.002 & 1734.5 & 21.45 & -2.501 & 0.066 & -0.0005 \\
\hline Gifu & 2169.1 & -13.56 & -0.077 & 0.004 & 1991.0 & 48.37 & -4.658 & 0.120 & -0.0009 \\
\hline Takayama & 1865.3 & 1.618 & -0.351 & 0.006 & 1762.3 & 37.42 & -2.999 & 0.072 & -0.0005 \\
\hline Hamamatsu & 2134.7 & -9.500 & 0.014 & 0.002 & 1991.8 & 40.19 & -3.661 & 0.094 & 0.0007 \\
\hline Yokohama & 1665.7 & 11.92 & -0.496 & 0.005 & 1420.8 & $97.13^{* *}$ & $-6.798 *$ & $0.164^{*}$ & -0.0013 \\
\hline
\end{tabular}

Remark:

$*$, ** show the significant coefficients at $5 \%$ and $1 \%$ levels of significance respectively. 
Demerits - The cyclic or periodic movement contained in secular variation cannot be examined since the original value is not directly used, and the various trend characters within the original secular values of annual rainfall amounts are not examined in detail.

Therefore, to eliminate such defects from the rank correlation method and to examine the cyclic movement of secular variation, the author tried fitting several polynomials to the secular variation of annual rainfall amonuts and gave these numerous results in Table 1.

Table 1 (d). Fitting results of several polynomials to the secular variations of annual rainfall amounts. $b_{0}$ is constant and $b_{i}(i=1,2,3,4)$ is coefficient estimated by maximum likelihood method.

\begin{tabular}{|c|c|c|c|c|c|c|c|c|c|}
\hline $\begin{array}{r}\text { polynomial } \\
\text { type }\end{array}$ & \multicolumn{4}{|c|}{3 rd order } & \multicolumn{5}{|c|}{4 th order } \\
\hline Station & $b_{0}$ & $b_{1}$ & $b_{2}$ & $b_{3}$ & $b_{0}$ & $b_{1}$ & $b_{2}$ & $b_{3}$ & $b_{4}$ \\
\hline Tokyo & 1548.3 & 11.45 & -0.410 & 0.003 & 1382.7 & $69.03 *$ & -4.667 & 0.111 & -0.0009 \\
\hline Chōshi & 1623.4 & 16.81 & -0.720 & 0.008 & 1389.8 & $98.03^{* *}$ & $-6.726 *$ & $0.159 *$ & -0.0012 \\
\hline Mito & 1394.1 & 17.79 & -0.765 & 0.008 & 1261.1 & $64.04 *$ & -4.186 & 0.094 & -0.0007 \\
\hline Utsunomiya & 1629.2 & -0.857 & -0.069 & 0.000 & 1486.4 & 48.82 & -3.743 & 0.093 & -0.0007 \\
\hline Maebashi & 1273.7 & 9.079 & -0.484 & 0.006 & 1092.5 & $72.09 *$ & $-5.144 *$ & 0.123 & -0.0009 \\
\hline Kumagaya & 1371.8 & -5.680 & 0.145 & -0.001 & 1182.3 & $60.23^{*}$ & -4.729 & 0.122 & -0.0010 \\
\hline Kōfu & 1260.1: & -0.164 & -0.044 & -0.001 & 1141.9 & 40.93 & -3.803 & 0.077 & -0.0006 \\
\hline Nagano & 1021. 3 & -0.158 & -0.090 & 0.002 & 922.9 & 34.06 & -2.621 & 0.066 & -0.0005 \\
\hline Matsumoto & 1193.8 & -4.211 & -0.108 & 0.003 & 1056.8 & 43.44 & -3.632 & 0.092 & -0.0007 \\
\hline Iida & 1927.6 & -17.39 & 0.083 & 0.003 & 1787.2 & 31.41 & -3.525 & 0.094 & -0.0007 \\
\hline Tsuruga & 2109.0 & $25.59 *$ & -0.772 & 0.008 & 1945.8 & $82.37 * *$ & -4.971 & 0.114 & -0.0009 \\
\hline Fukui & 2352.0 & 14.72 & -0.761 & 0.010 & 2262.2 & 45.96 & -3.072 & 0.068 & -0.0005 \\
\hline Kanazawa & 2647.2 & 0.382 & -0.460 & 0.008 & 2565.1 & 28.91 & -2.570 & 0.062 & -0.0004 \\
\hline Fushiki & 2231.1 & 6.127 & -0.452 & 0.007 & 2172.5 & 26.53 & -1.961 & 0.045 & -0.0003 \\
\hline Niigata & 1910.2 & -6.454 & -0.084 & 0.003 & 1844.4 & 16.44 & -1.777 & 0.046 & -0.0003 \\
\hline Fukushima & 1139.1 & 15.98 & -0.713 & 0.008 & 982.9 & $70.27 *$ & -4.728 & 0.109 & -0.0008 \\
\hline Ishinomaki & 1118.9 & 6.852 & -0.376 & 0.005 & 1011.8 & 44.09 & -3.131 & 0.074 & -0.0006 \\
\hline Miyako & 1391.0 & 5.558 & -0.502 & 0.007 & 1240.4 & $57.95^{*}$ & -4.377 & 0.105 & -0.0008 \\
\hline Yamagata & 1166.9 & 8.995 & -0.288 & 0.003 & 1106.2 & 30.10 & -1.849 & 0.042 & -0.0003 \\
\hline Akita & 1790.4 & 9.215 & -0.502 & 0.006 & 1783.1 & 11.75 & -0.691 & 0.011 & -0.0000 \\
\hline Aomori & 1345.5 & 3.752 & 0.004 & -0.001 & 1190.5 & $57.68 *$ & -3.984 & 0.100 & -0.0008 \\
\hline Hakodate & 1042.2 & 16.76 & -0.459 & 0.003 & 1077.4 & 4.525 & 0.445 & -0.019 & 0.0002 \\
\hline Obihiro & 845.88 & 17.13 & -0.633 & 0.006 & 801.6 & 32.51 & -1.771 & 0.035 & -0.0002 \\
\hline Suttsu & 965.32 & $32.90^{*}$ & $-0.944 *$ & 0.008 & 1104.0 & -15.32 & 2.622 & -0.081 & 0.0007 \\
\hline Sapporo & 906.35 & 16.73 & -0.424 & 0.004 & 927.1 & 9.487 & 0.111 & -0.010 & 0.0001 \\
\hline Asahikawa & 981.11 & 12.76 & -0.395 & 0.004 & 939.0 & 27.38 & -1.476 & 0.031 & -0.0002 \\
\hline Abashiri & 675.51 & $23.70 *$ & -0.743 & 0.007 & 650.5 & 32.41 & -1.387 & 0.023 & -0.0001 \\
\hline Nemuro & 748.29 & $33.27 * *$ & $-1.094 *$ & 0.011 & 781.0 & 21.90 & -0.253 & -0.010 & 0.0002 \\
\hline
\end{tabular}

Remark :

*,** show the significant coefficients at $5 \%$ and $1 \%$ levels of significance respectively. 
In Table 1, "Mean" is short for the normal mean values of annual rainfall computed in the period range 1900-1963, so slightly different from the similar result shown in Fig. 22 presented at the previous paper of the author (1967), because the range of computed data is equivalent to possible maximum period length (from the commencement year to 1963) for each station in that Fig. 22.

However, these differences are so sufficiently small that are almost negligible for the computations in this chapter. The computed coefficients are shown by the same notation $b_{0}, b_{1}$ and $b_{2}$, etc. as population coefficients, and they are generally obtained by the maximum likelihood method. In Table 1 , The symbols * and ** mean the statistically significant terms at the $5 \%$ level and $1 \%$ levels respectively, where

Table 1 (e). Fitting results of several polynomials to the secular variations of annual rainfall amounts. Computed values of variance.

\begin{tabular}{|c|c|c|c|c|c|c|}
\hline Station & Var. $R_{y}$ & $\operatorname{Var} . \varepsilon_{1}$ & $\operatorname{Var} . \varepsilon_{2}$ & Var. $\varepsilon_{3}$ & $\operatorname{Var} . \varepsilon_{4}$ & $r\left(R_{y}, t\right)$ \\
\hline Kagoshima & 213198 & 210829 & 192040 & 189673 & 168793 & 0.105 \\
\hline Miyazaki & 215040 & 214470 & 213809 & 212606 & 205883 & 0.052 \\
\hline Kumamoto & 124676 & 124600 & 110147 & 110002 & 106633 & 0.025 \\
\hline Nagasaki & 147587 & 147231 & 146951 & 146558 & 143269 & 0.049 \\
\hline Izuhara & 165531 & 163149 & 159174 & 152736 & 151909 & -0.120 \\
\hline Saga & 101668 & 98494 & 93531 & 93524 & 91141 & 0.177 \\
\hline Fukuoka & 75023 & 74016 & 69479 & 68587 & 63385 & 0.116 \\
\hline Ōita & 97339 & 97245 & 92754 & 92325 & 86905 & 0.031 \\
\hline Shimonoseki & 75470 & 75254 & 72624 & 72623 & 64737 & 0.053 \\
\hline Kōchi & 213724 & 213528 & 208040 & 206707 & 204271 & -0.030 \\
\hline Tokushima & 101612 & 101494 & 94989 & 94814 & 89049 & -0.034 \\
\hline Tadotsu & 36276 & 36019 & 35802 & 35801 & 34617 & -0.084 \\
\hline Matsuyama & 59770 & 59122 & 58317 & 56630 & 53697 & -0.104 \\
\hline Hiroshima & 80681 & 79577 & 77139 & 77051 & 72801 & 0.117 \\
\hline Okayama & 39688 & 39234 & 37955 & 37912 & 36078 & 0.107 \\
\hline Hamada & 110814 & 106738 & 105950 & 103402 & 102459 & 0.192 \\
\hline Sakai & 62591 & 61933 & 61469 & 60480 & 60026 & 0.103 \\
\hline Kōbe & 47700 & 47378 & 46069 & 45398 & 44864 & 0.082 \\
\hline Ōsaka & 49989 & 49978 & 45176 & 44864 & 43705 & 0.015 \\
\hline Wakayama & 97254 & 97098 & 89894 & 89894 & 85941 & -0.040 \\
\hline Kyoto & 73344 & 72912 & 64734 & 64124 & 61207 & 0.076 \\
\hline Hikone & 69690 & 69251 & 60304 & 57644 & 57257 & 0.079 \\
\hline Tsu & 88722 & 87233 & 83626 & 82418 & 80570 & -0.130 \\
\hline Nagoya & 68395 & 63978 & 59671 & 59582 & 58085 & -0.254 \\
\hline Gifu & 95414 & 92575 & 82752 & 82315 & 77436 & -0.172 \\
\hline Takayama & 82442 & 82261 & 79795 & 79101 & 77470 & -0.047 \\
\hline Hamamatsu & 124753 & 122532 & 119843 & 119777 & 116637 & -0.133 \\
\hline Yokohama & 87731 & 86376 & 86191 & 85668 & 76429 & -0.124 \\
\hline
\end{tabular}

Note:

$r\left(R_{y}, t\right)$ shows a sample correlation coefficient between $R_{y}$ and year $t$. 
the significance test is easily done by $\chi^{2}$-distribution as was already shown in the above section. The quantity Var. $R_{y}$ is the sample variance of annual rainfall amount showing the up-and-down variation scale around a normal mean value, and also the quantities Var. $\varepsilon_{1}$, Var. $\varepsilon_{2}$, Var. $\varepsilon_{3}$ and Var. $\varepsilon_{4}$ are the sample residual variances of annual rainfall amounts from the fitted 1st, $2 \mathrm{nd}$, 3rd and the 4th order polynomials respectively.

Geographical distributions of these coefficients are shown in Fig. 3 in the summarized form.

Firstly, in fitting the linear trend $R_{y}(t) \fallingdotseq b_{0}+b_{1} t$, the estimated coefficient $b_{1}$ has

Table $1(f)$. Fitting results of several polynomials to the secular variations of annual rainfall amounts. Computed values of variance.

\begin{tabular}{|c|c|c|c|c|c|c|}
\hline Station & Var. $R_{y}$ & $\operatorname{Var} . \varepsilon_{1}$ & Var. $\varepsilon_{2}$ & Var. $\varepsilon_{3}$ & $\operatorname{Var} . \varepsilon_{4}$ & $r\left(R_{y}, t\right)$ \\
\hline Tokyo & 72701 & 71496 & 70828 & 70559 & 66342 & -0.129 \\
\hline Chōshi & 80573 & 80340 & 80150 & 78637 & 70243 & 0.054 \\
\hline Mito & 43142 & 41841 & 41785 & 40375 & 37653 & -0.174 \\
\hline Utsunomiya & 60619 & 56145 & 56067 & 56063 & 52924 & -0.271 \\
\hline Maebashi & 40218 & 39738 & 39573 & 38857 & 33805 & -0.109 \\
\hline Kumagaya & 49265 & 49030 & 48929 & 48897 & 43372 & -0.069 \\
\hline Kōfu & 62590 & 62370 & 62359 & 62351 & 60203 & -0.059 \\
\hline Nagano & 23640 & 23629 & 23214 & 23148 & 21659 & 0.021 \\
\hline Matsumoto & 42299 & 4.1313 & 39649 & 394.93 & 36605 & -0.153 \\
\hline Iida & 69056 & 67295 & 56672 & 56491 & 53463 & -0.160 \\
\hline Tsuruga & 113375 & 99828 & 99826 & 98311 & 94207 & 0.345 \\
\hline Fukui & 76620 & 75984 & 74158 & 72044 & 70801 & 0.091 \\
\hline Kanazawa & 96750 & 96524 & 87878 & 86335 & 85300 & 0.048 \\
\hline Fushiki & 69390 & 67372 & 63877 & 62782 & 62252 & 0.171 \\
\hline Niigata & 44786 & 44785 & 40206 & 39953 & 39287 & 0.003 \\
\hline Fukushima & 33393 & 32817 & 32813 & 31480 & 27729 & -0.131 \\
\hline Ishinomaki & 36241 & 36121 & 35915 & 35449 & 33684 & -0.057 \\
\hline Miyako & 69587 & 68251 & 66807 & 65780 & 62287 & -0.139 \\
\hline Yamagata & 24437 & 24406 & 24246 & 24091 & 23524 & 0.036 \\
\hline Akita & 59163 & 59150 & 58604 & 57734 & 57725 & -0.015 \\
\hline Aomori & 40388 & 40373 & 39544 & 39518 & 35819 & 0.019 \\
\hline Hakodate & 23679 & 23656 & 21600 & 21360 & 21170 & -0.031 \\
\hline Obihiro & 28209 & 28200 & 28015 & 27128 & 26826 & -0.018 \\
\hline Suttsu & 36535 & 34718 & 31371 & 29928 & 26973 & 0.223 \\
\hline Sapporo & 20442 & 17633 & 16921 & 16634 & 16567 & 0.371 \\
\hline Asahikawa & 25806 & 24132 & 24094 & 23732 & 23460 & 0.254 \\
\hline Abashiri & 20845 & 20778 & 19244 & 18283 & 18186 & 0.057 \\
\hline Nemuro & 36098 & 32048 & 31542 & 28874 & 28710 & 0.334 \\
\hline
\end{tabular}

Note:

$r\left(R_{y}, t\right)$ shows a sample correlation coefficient between $R_{y}$ and year $t$. 


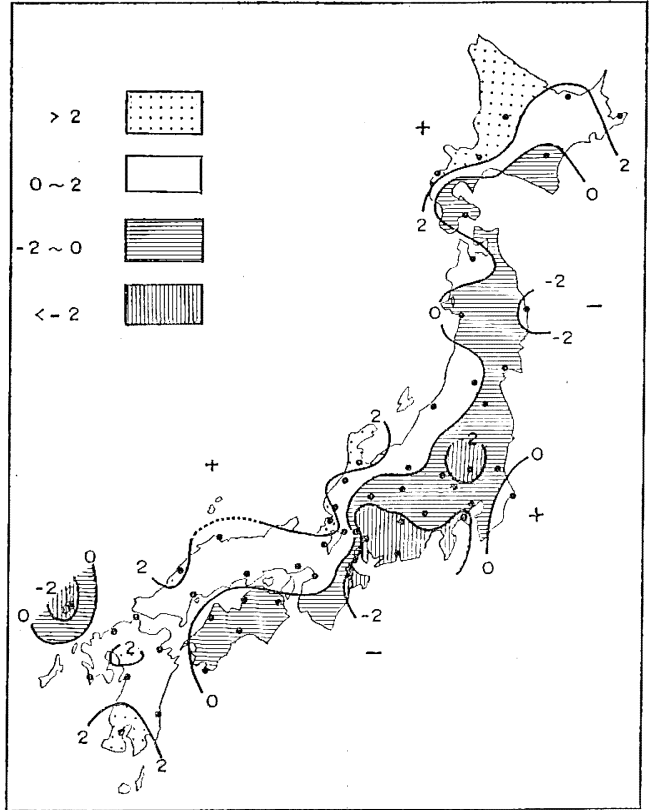

Fig. 3 (a). Geographical distribution of coefficient $b_{1}$ in fitting linear trend $y$ $\doteqdot b_{0}+b_{1} t(1960-1963, y$ : annual data, $t$ : year).

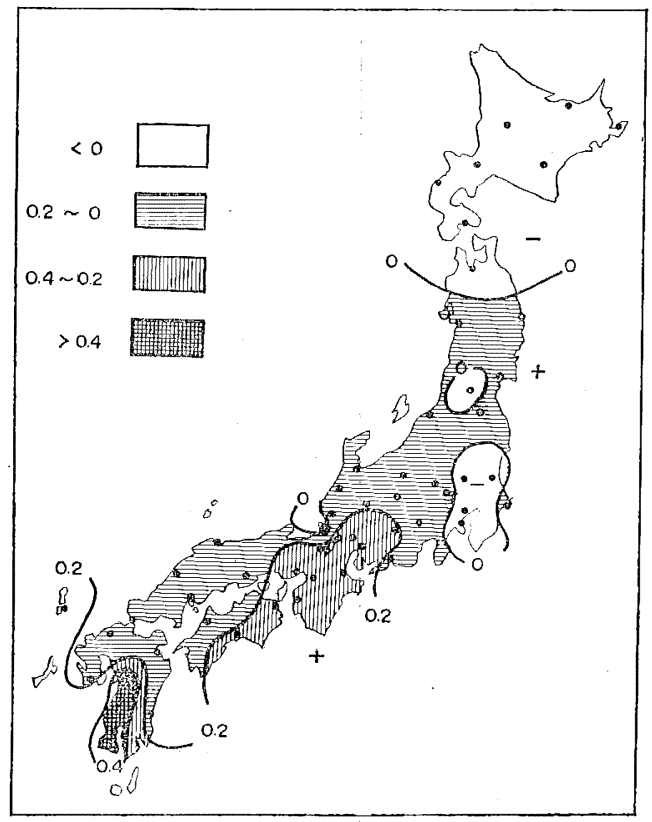

Fig. 3 (c). Geographical distribution of $b_{2}$ in fitting quadratic trend $y \doteqdot b_{0}+$ $b_{1} t+b_{2} t^{2} \quad(1900-1963, y$ : annual data, $t$ : year).

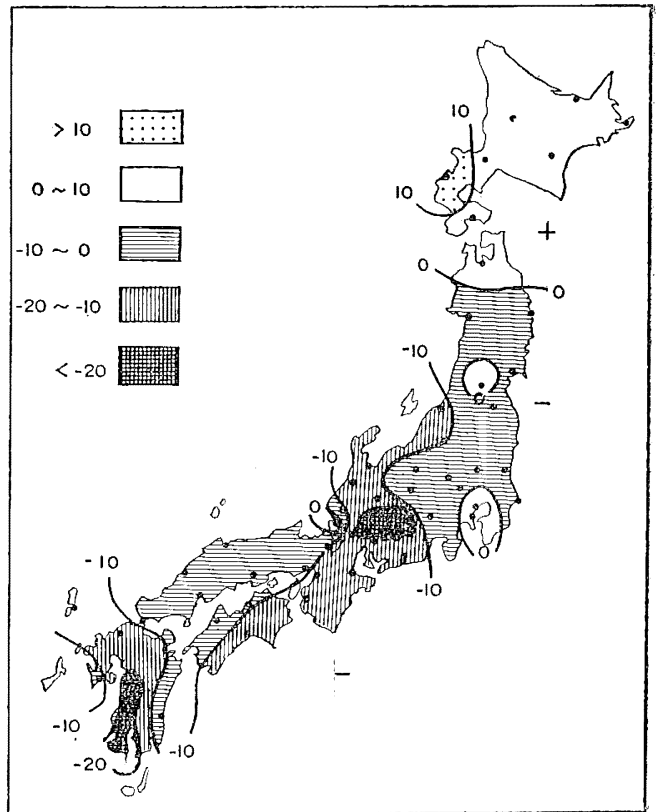

Fig. 3 (b). Geographical distribution of $b_{1}$ in fitting quadratic trend $y \fallingdotseq b_{0}+$ $b_{1} t+b_{2} t^{2}(1900-1963, y$ : annual data, $t$ : year).

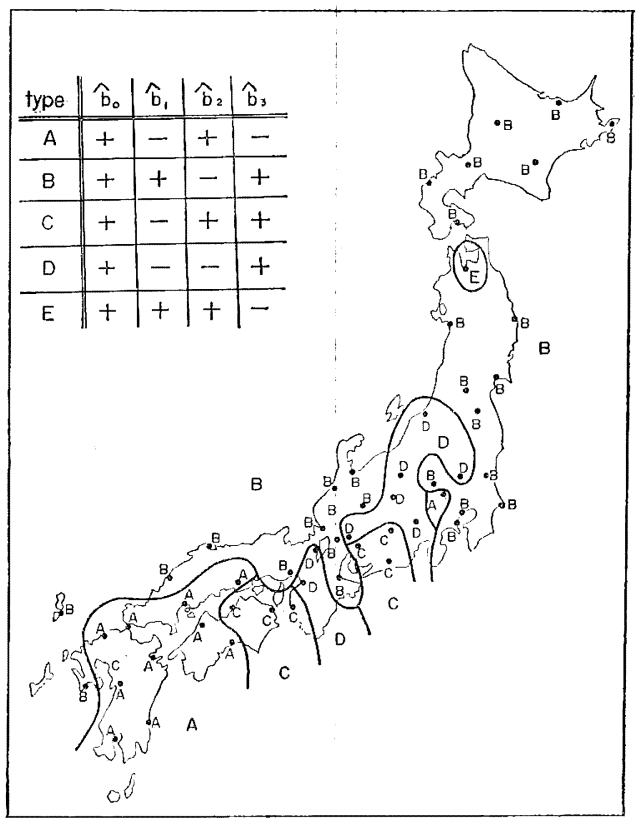

Fig. $3(\mathrm{~d})$. Geographical type classification by the coefficients of $y \fallingdotseq \hat{b}_{0}+\hat{b}_{1} t+\hat{b}_{2} t^{2}$ $+\hat{b}_{3} t^{3}(1900-1963, y$ : annual data, $t$ : year). 


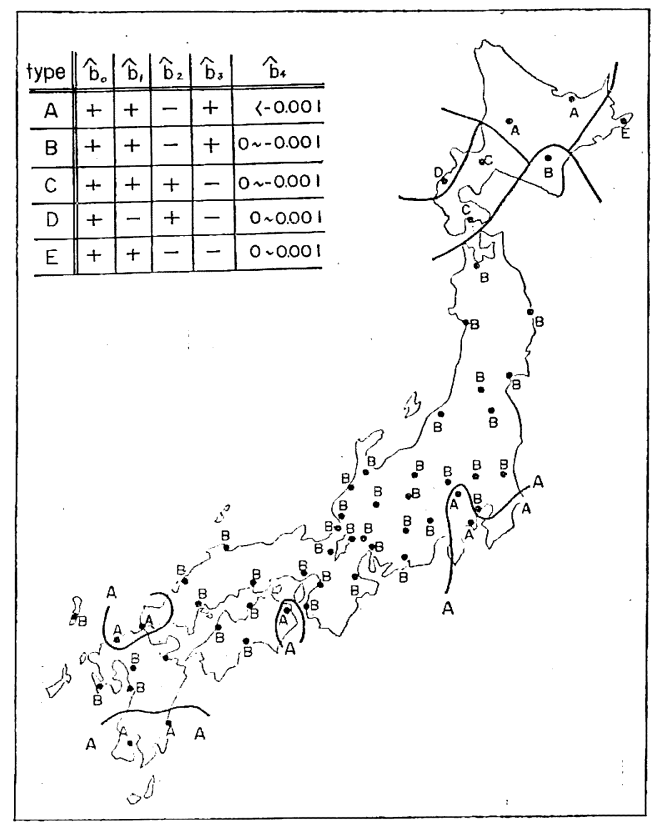

Fig. 3 (e). Geographical type classification by the coefficients of $y \doteqdot$ $\hat{b}_{0}+\hat{b}_{1} t+\hat{b}_{2} t^{2}+\hat{b}_{3} t^{3}+\hat{b}_{4} t^{4}(1900-1963, y:$ annual data, $t:$ year $)$.

completely the same sign as $I_{T}$ and the absolute value of $b_{1}$ is almost proportional to the absolute value of $I_{T}$ over the whole domain of Japan, as is reasonably expected.

Secondly, in fitting the quadratic trend $R_{y}(t) \fallingdotseq b_{0}+b_{1} t+b_{2} t^{2}$, coefficients $b_{1}$ are of course different from coefficients $b_{1}$ of the linear trend and geographical distributions of $b_{1}$ and $b_{2}$ are also shown in Fig. 3. A somewhat different trend structure can be clarified for the same increasing regions of $I_{T}$. For example, a typical quadratic increasing trend is seen in the western part of Japan and a linear increasing trend at Hokkaidō and the occurrence situations of maximum and minimum are evidently different between the Japan Sea side and the Pacific Ocean side of Japan. This is in agreement with the conclusion to be arrived at by T. SEKIGUCHI (1964).

Thirdly, in fitting the cubic and the 4th order polynomial, classified trend types are geographically shown in Fig. 3, since geographical distributions of various coefficient values are quite complicated and inconvenient for geographical comparison.

Lastly, in order to show the synthetic results of trend analysis, the author must compare Fig. 22 showing geographical distributions of variability and persistency by mean difference and Goutereau ratio etc. presented at the author's previous paper (1967) with Fig. 2 showing geographical distribution of trend index $I_{T}$ and also with Fig. 3 showing polynomial fitting to secular annual rainfall variation in detail as far as possible. Thus the following summarized results are obtained:

(a) Among the significant increasing regions due to primitive trend analysis performed by computing trend index $I_{T}$, the Kyushū district has a negative persistent tendency 
(up-and-down tendency) and a quadratic (cyclic in a wide sense) trend with conspicuous variation, while the Hokkaido district has the rather positive persistency and a linear increasing trend (monotone in a long range scale) with comparatively small variation.

Moreover, in the intermediate region between these two far distant districts, both Chūgoku and Hokuriku districts have neithr positive nor negative persistency. These two districts have conspicuous or significant increasing trends but these increasing features are neither linear nor quadratic.

(b) Among the significant decreasing regions shown by (a), the northern Kantō district has no apparent persistency and variability and has a linear decreasing trend with small variation, while both Tōkai and Chūbu districts have small positive

Table 2 (a). Estimated results of maximum and minimum years appearing in secular variation by fitting polynomials.

\begin{tabular}{|c|c|c|c|c|c|c|c|c|c|}
\hline \multirow{2}{*}{ trend type } & \multicolumn{2}{|c|}{ 2nd Order } & \multicolumn{3}{|c|}{ 3rd Order } & \multicolumn{4}{|c|}{ 4th Order } \\
\hline & Max. & Min. & Max. & Min. & Max. & Max. & Min. & Max. & Min. \\
\hline Kagoshima & & 1928 & & 1923 & - & 1909 & 1931 & 1955 & \\
\hline Miyazaki & & 1924 & & 1918 & 1952 & 1908 & 1928 & 1952 & \\
\hline Kumamoto & & 1930 & & 1929 & - & 1904 & 1930 & 1956 & \\
\hline Nagasaki & & 1922 & 1915 & 1938 & & 1911 & 1932 & 1954 & \\
\hline Izuhara & & 1937 & 1910 & 1942 & & 1910 & 1940 & - & \\
\hline Saga & & 1925 & & 1925 & - & 1908 & 1929 & 1957 & \\
\hline Fukuoka & & 1927 & & 1922 & - & 1906 & 1928 & 1953 & \\
\hline Ōita & & 1930 & & 1925 & - & 1907 & 1929 & 1953 & \\
\hline Shimonoseki & & 1929 & & 1928 & 一 & 1909 & 1931 & 1954 & \\
\hline Kōchi & & 1932 & & 1925 & 1959 & 1902 & 1928 & 1953 & \\
\hline Tokushima & & 1932 & & 1935 & - & 1908 & 1932 & 1955 & \\
\hline Tadotsu & & 1940 & & 1941 & - & 1909 & 1932 & 1952 & \\
\hline Matsuyama & & 1938 & & 1922 & 1947 & 1905 & 1928 & 1.950 & \\
\hline Hiroshima & & 1926 & & 1923 & - & 1908 & 1929 & 1954 & \\
\hline Okayama & & 1926 & & 1924 & - & 1908 & 1929 & 1954 & \\
\hline Hamada & & 1913 & 1919 & 1938 & & 1914 & 1934 & 1962 & \\
\hline Sakai & & 1921 & 1915 & 1938 & & 1912 & 1936 & - & \\
\hline Kōbe & & 1927 & 1910 & 1937 & & 1910 & 1933 & 1962 & \\
\hline Ōsaka & & 1931 & & 1935 & - & 1907 & 1933 & 1960 & \\
\hline Wakayama & & 1932 & & 1933 & - & 1906 & 1931 & 1955 & \\
\hline Kyōto & & 1929 & & 1934 & - & 1908 & 1932 & 1959 & \\
\hline Hikone & & 1929 & 1905 & 1937 & & 1908 & 1935 & - & \\
\hline Tsu & & 1936 & & 1941 & - & 1908 & 1936 & 1959 & \\
\hline Nagoya & & 1939 & & 1941 & - & 1905 & 1935 & 1956 & \\
\hline Gifu & & 1935 & & 1938 & - & 1907 & 1933 & 1956 & \\
\hline Takayama & & 1933 & 1903 & 1940 & & 1909 & 1934 & 1958 & \\
\hline Hamamatsu & & 1938 & & 1941 & - & 1907 & 1933 & 1954 & \\
\hline Yokohama & 1909 & & 1916 & 1953 & & 1911 & 1933 & 1951 & \\
\hline
\end{tabular}

Remark:- denotes the year after 1963 
Tabbe $2(\mathrm{~b})$. Estimated results of maximum and minimum years appearing in secular variation by fitting polynomials.

\begin{tabular}{|c|c|c|c|c|c|c|c|c|c|}
\hline \multirow{2}{*}{$\begin{array}{l}\text { trend type } \\
\text { Station }\end{array}$} & \multicolumn{2}{|c|}{ 2nd Order } & \multicolumn{3}{|c|}{ 3rd Order } & \multicolumn{4}{|c|}{ 4th Order } \\
\hline & Max. & Min. & Max. & Min. & Max. & Max. & Min. & Max. & Min. \\
\hline Tokyo & 1920 & & 1918 & 1961 & & 1912 & 1934 & 1950 & \\
\hline Chōshi & & 1922 & 1916 & 1942 & & 1911 & 1933 & 1954 & \\
\hline Mito & & - & 1915 & 1949 & & 1912 & 1937 & 1953 & \\
\hline Utsunomiya & & - & - & - & & 1910 & 1934 & 1949 & \\
\hline Maebashi & & 1945 & 1912 & 1945 & & 1911 & 1934 & 1953 & \\
\hline Kumagaya & & 1943 & & 1933 & 1948 & 1909 & 1931 & 1952 & \\
\hline Kōfu & & 1963 & & 1951 & - & 1910 & 1932 & 1952 & \\
\hline Nagano & & 1930 & & 1936 & - & 1910 & 1932 & 1954 & \\
\hline Matsumoto & & 1937 & & 1941 & - & 1908 & 1933 & 1954 & \\
\hline Iida & & 1934 & & 1937 & - & 1906 & 1933 & 1957 & \\
\hline Tsuruga & $\longrightarrow$ & & - & - & & 1914 & 1929 & 1956 & \\
\hline Fukui & & 1926 & 1913 & 1940 & & 1911 & 1935 & - & \\
\hline Kanazawa & & 1930 & & 1937 & - & 1908 & 1934 & - & \\
\hline Fushiki & & 1925 & 1908 & 1935 & & 1910 & 1933 & - & \\
\hline Niigata & & 1931 & & 1935 & - & 1906 & 1933 & 1962 & \\
\hline Fukushima & & - & 1915 & 1947 & & 1911 & 1935 & 1954 & \\
\hline Ishinomaki & & 1937 & 1912 & 1943 & & 1911 & 1934 & 1954 & \\
\hline Miyako & & 1939 & 1906 & 1943 & & 1910 & 1935 & 1955 & \\
\hline Yamagata & 1935 & & 1923 & 1950 & & 1912 & 1934 & 1952 & \\
\hline Akita & & 1932 & 1912 & 1942 & & 1911 & 1941 & - & \\
\hline Aomori & 1932 & & 1935 & - & & 1912 & 1930 & 1950 & \\
\hline Hakodate & 1930 & & 1925 & - & & 1928 & 1956 & - & \\
\hline Obihiro & 1929 & & 1919 & 1948 & & 1915 & 1941 & 1958 & \\
\hline Suttsu & 1937 & & 1926 & 1952 & & & 1903 & 1930 & 1952 \\
\hline Sapporo & 1946 & & - & - & & 1933 & 1948 & - & \\
\hline Asahikawa & - & & 1929 & 1937 & & 1917 & 1931 & 1959 & \\
\hline Abashiri & 1933 & & 1923 & 1953 & & 1920 & 1960 & - & \\
\hline Nemuro & 1954 & & 1923 & 1943 & & 1926 & 1946 & - & \\
\hline
\end{tabular}

Remark:- denotes the year after 1963

persistency and have a quadratic decreasing trend with slowly up-and-down variation.

(c) The several maximum or minimum years that appeared in the secular variation of annual rainfall amounts are shown in Table 2 as a summarized result of polynomial fitting. Large scale cyclic movements can be described in this table. For example, the maximum year is easily seen in 1905-1915 and the minimum year is appeared in 1925-1935, and the maximum year is again noticed in the recent period 1952-1962 in the greater part of western Japan.

On the contrary, no systematic tendency can be seen at all and the Hokkaido district shows a quite different tendency from the other districts of Japan.

Besides, several more detailed results may be derived from the authors work in 
this field, and they will be explained by comparison with the foregoing past studies by other scholars: K. TAKAHASHI (1956) discussed the secular variations of annual rainfall amounts in relation to the sun-spot number at several points in Japan and $T$. YAMAMOTO (1958) studied the secular trend of annual rainfall through dividing annual rainfall into that of the warmer half year and that of the colder half year. However their studies were based on annual rainfall data obtained at only a small number of observation points as compared with the author's study, and consequently their results are not always satisfactory. And T. SEKIGUCHI (1964) performed synthetic investigation concerning the secular variations of annual rainfall amounts by use of the residual mass curve at about 70 observation points, and it will be meaningful to compare his synthetic results to the author's. The gists of the comparison will be given in an itemized form as follows:

(i) T. SekiguchI divided the whole of Japan into three regions (Japan Sea side, Pacific Ocean side and Hokkaidō) with reference to the secular trend of annual rainfall amounts. In the geographical distribution of trend index $I_{T}$ due to the author, the isoline showing the equality $I_{T}=0$ divides the whole of Japan into three regions which are practically the same as T. SEKIGUCHI, exept for the treatment of Obihiro and Hakodate in Hokkaidō. Moreover, such rough trend characters have been clarified in detail by the other two approaches (polynomial fitting and computing of the statistical quantities of variability and persistency).

(ii) T. SeKigUchI took up the increasing trend of the Pacific Ocean side as a conspicuous character, and exemplified it by actual secular variations at Osaka, Gifu and Maebashi. However, according to analysis based on trend index $I_{T}$, the Pacific Ocean side of Japan is considered as a decreasing tendency region and the Japan Sea side of Japan is considered as an increasing tendency region on the contray to his results. Moreover the southern part of the Chübu district; has a significant decreasing trend as is seen in the long range secular variations of annual rainfall amounts at Gifu, Nagoya, Iida and Kôfu. After all results contrary to what was pointed out by $T$. SEKIGUCHI are obtained for these observation points.

As the main reason for this discrepancy, the following must be noted:

$T$. SEKIGUCHI pointed out a recent increasing trend at Gifu, for example, but no such tendency is seen over the whole period, and in fact the significant decreasing trend is already indicated in the next two books already:

E. FUKUI: "General Climatology," published by Asakura Shoten (1961) p. 126.

K. WADATI (ed): "Climate of Japan" published by Tōkyō-dō (1958) p. 24.

In these books, the rainfall amount is shown to be generally larger in the summer season than in the winter season at Gifu, and has a remarkable decreasing tendency over the long period between 1900 and 1947. This tendency is never offset by the recent increasing period being pointed out by $T$. SEKIGUCHI.

(iii) T. SEKIGUCHI pointed out that the Japan Sea side has no apparent increasing or decreasing trend, but, seeing trend index $I_{T}$, the western part of the Hokuriku district, San-in district and the northern part of the Kyushū district, etc. have conspicuous or significant increasing trends and the details of such increasing trends are more clarified by polynomial fitting and analysis of variability or persistency referred to already.

As is shown in the above book written by E. FUKUI (1961), a heavy snowfall tendency appears rather clearly at the Hokuriku district in winter, and $T$. SEKIGUCHI pointed out a remarkable increasing tendency in the years after 1950 
without mentioning the regions.

Then, the author would like to consider the western part of the Hokuriku district and the northern part of the Kyūshū district as the significantly increasing regions with conspicuous up-and-down variation.

\section{Secular variation in monthly rainfall amounts}

The author collected monthly rainfall amounts at 56 observation points where the commencement year of rainfall observation is 1900 or before, for each month of the year, and computed the trend index $I_{T}$ for the period range 1900-1963 to uniformalize the sample size of the stations in in Japan. The geographical distributions of the trend index $I_{T}$ are given by Fig. 4 .

No significant trend is seen to be predominant almost over half of the area of Japan in the general results shown by Fig. 4, since the regions satisfying two inequaltities $0 \geqq I_{T}>-1,1>I_{T} \geqq 0$ should be regarded as having no significant trends according to the judgement criterion based upon trend index $I_{T}$ in section 1 of this chapter, so the appearance of significant trends different from month to month is summarized on the whole in Table 3 for every month.

As is apparently shown in Fig. 4, the conspicuous or significant trends of decreasing and increasing are rather complicated and different from month to month in Japan, but a substantial explanation of increasing and decreasing trends appearing in annual rainfall amounts will be to some extent possible to do from the various results of Fig. 4 .

Therefore the author examined the monthly reason for the several significant

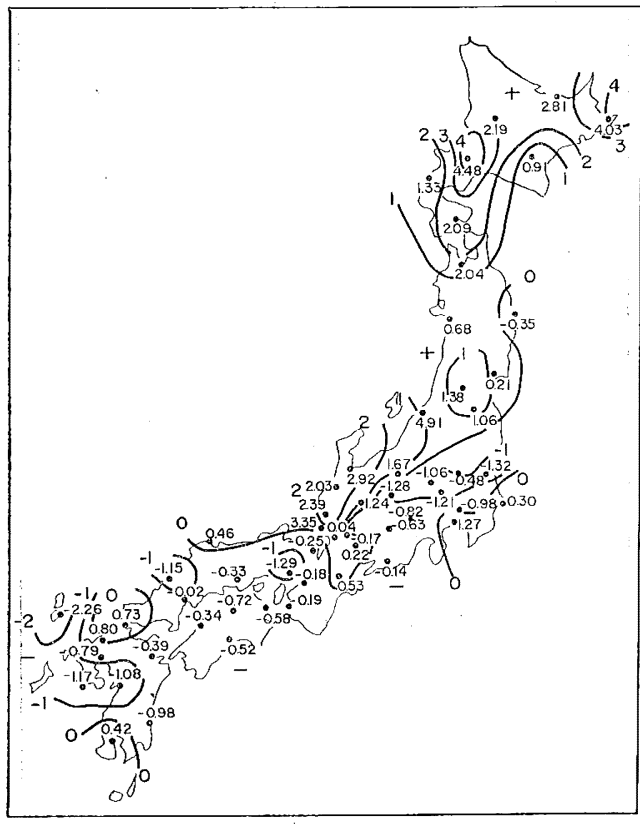

(a)

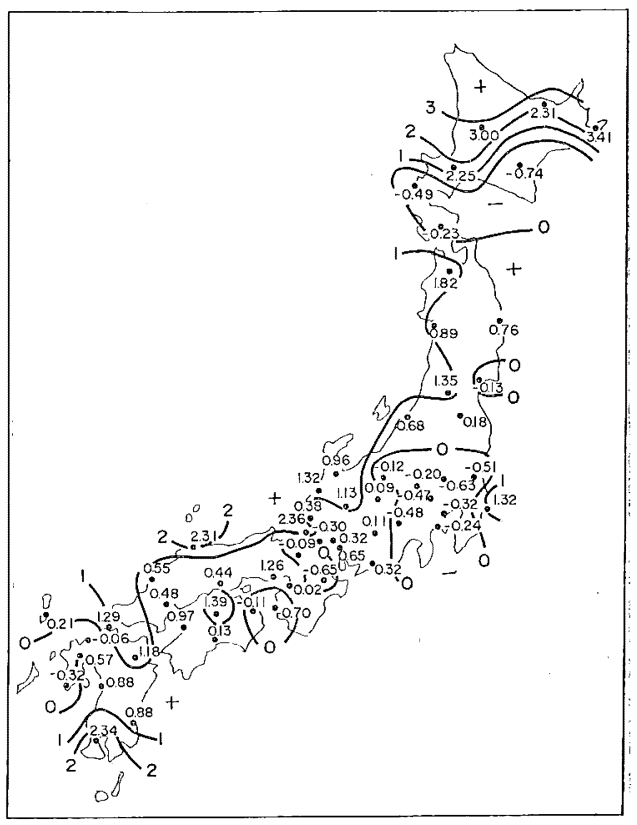

(b) 


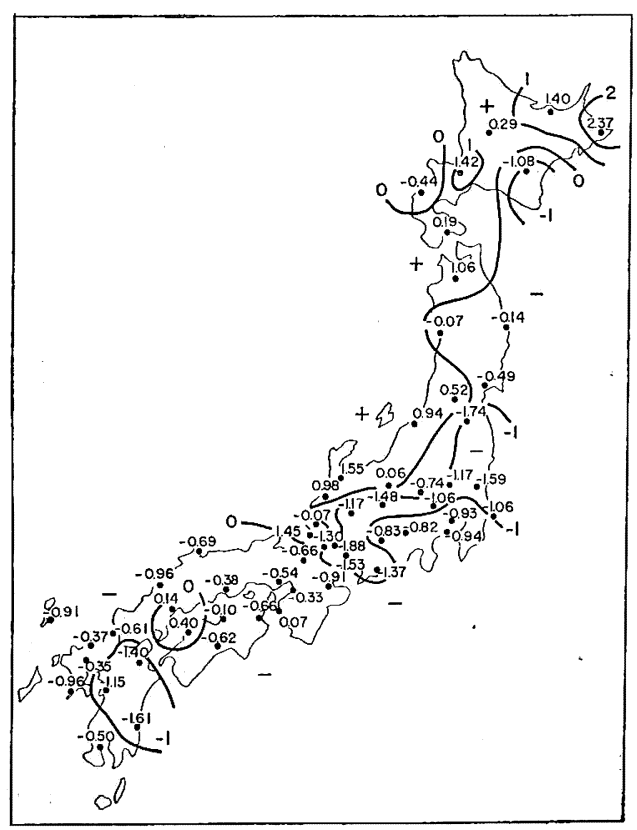

(c)

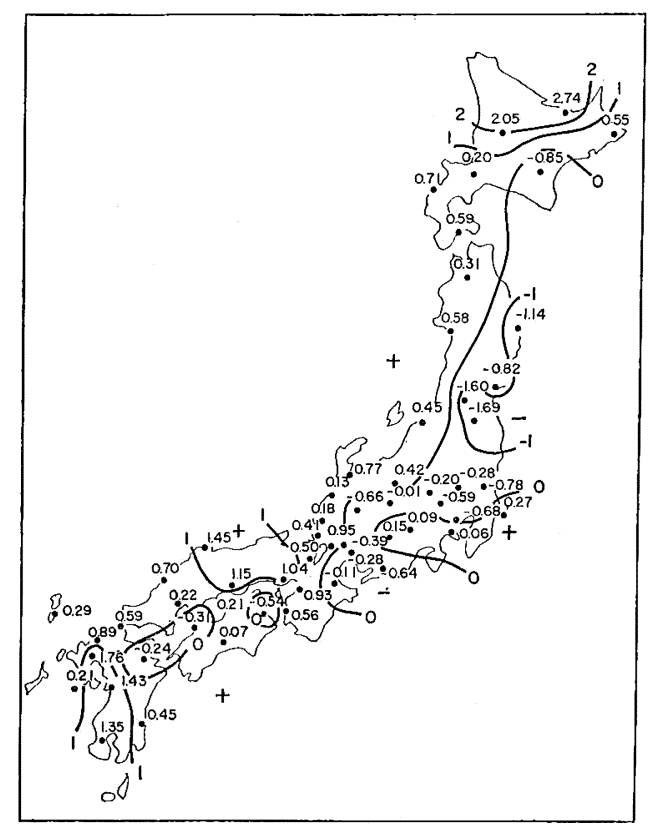

(e)

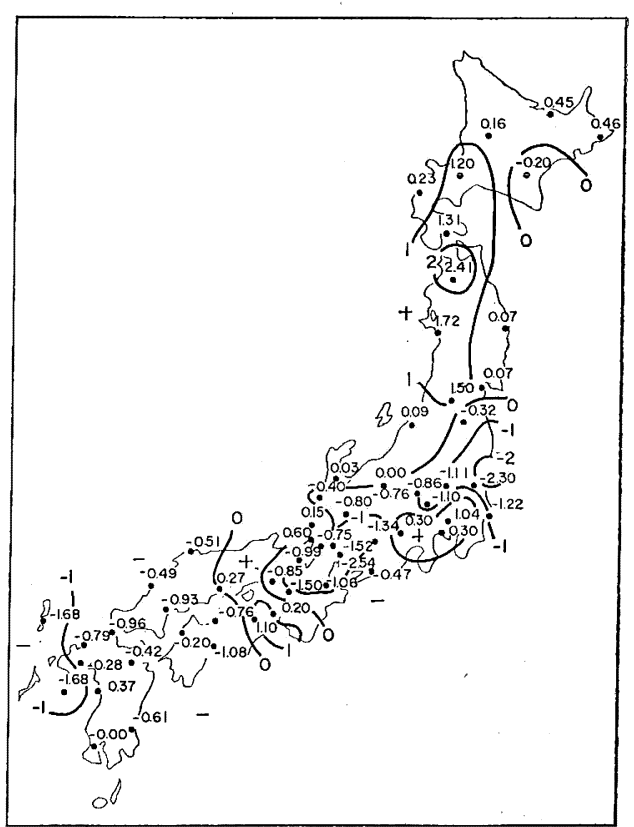

(d)

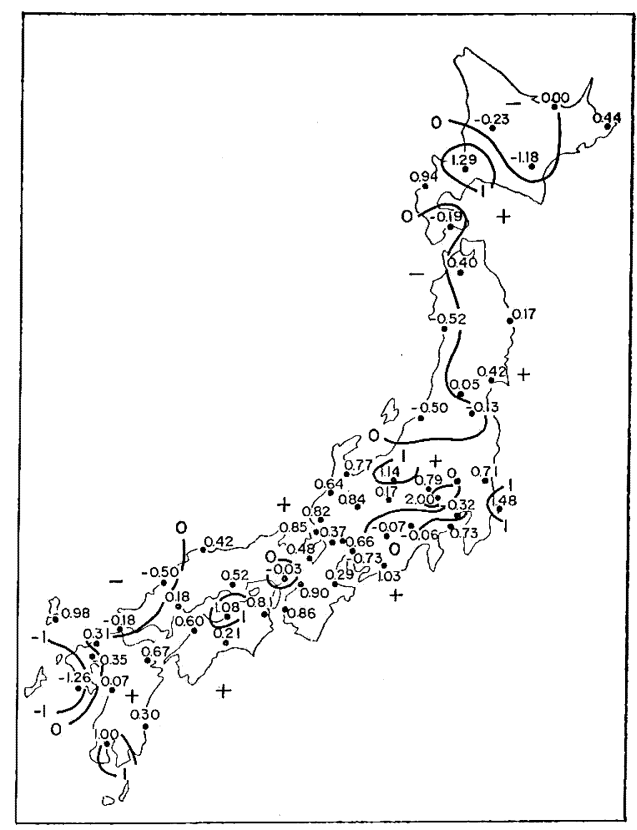

(f) 


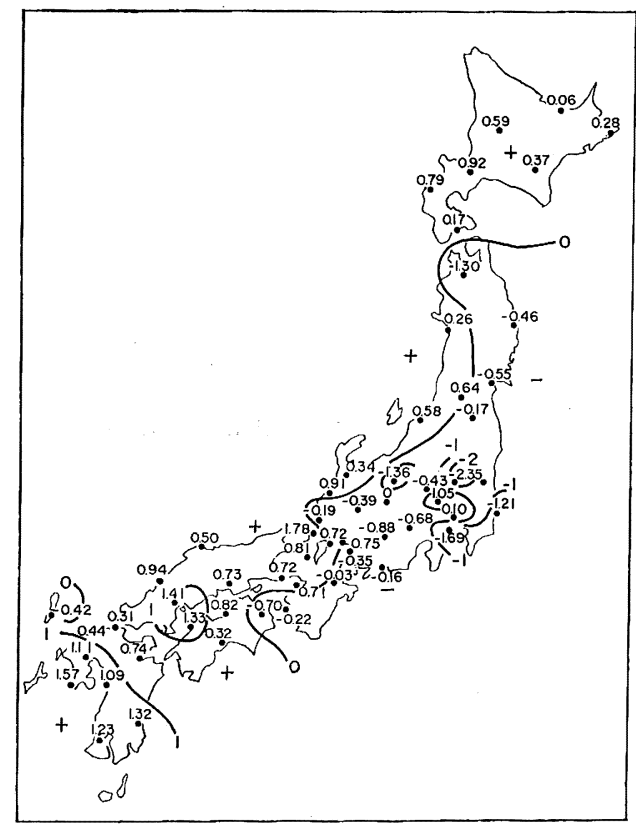

(g)

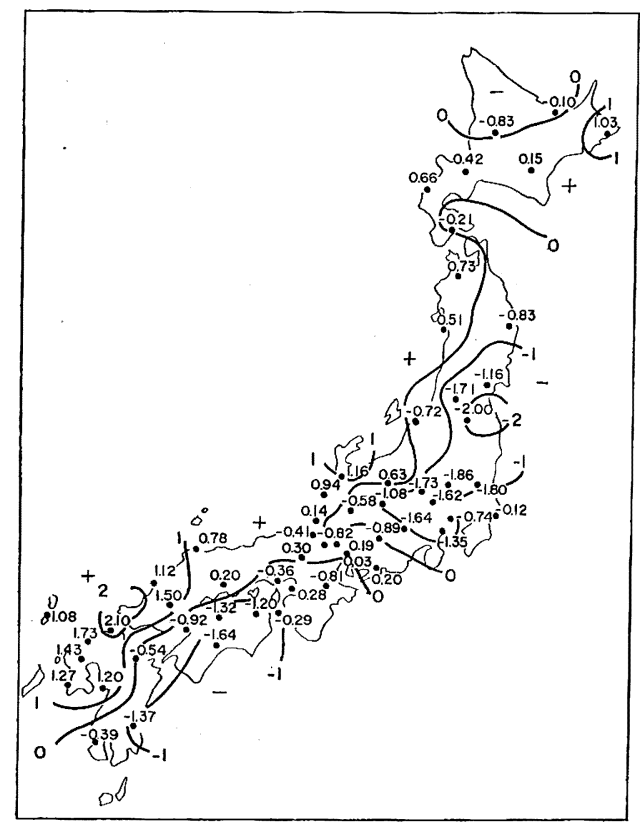

(i)

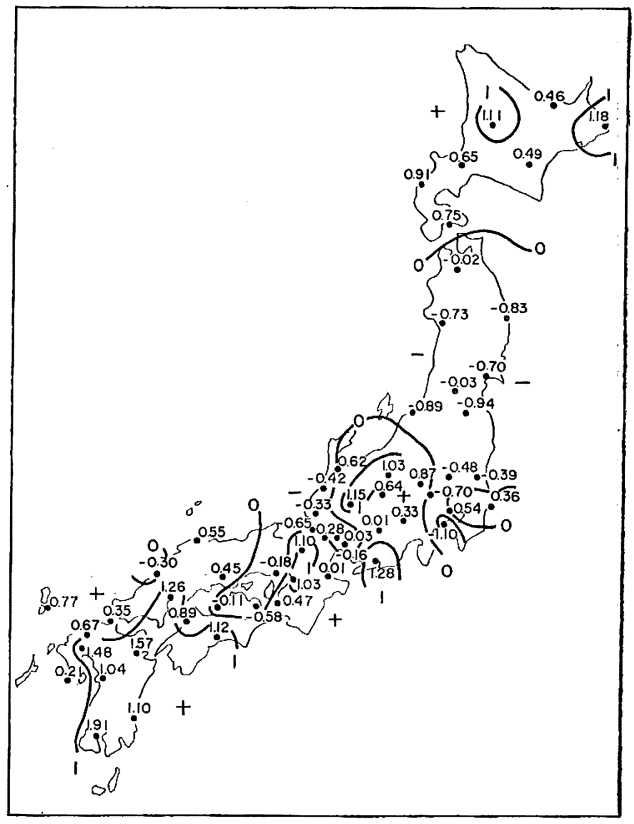

(h)

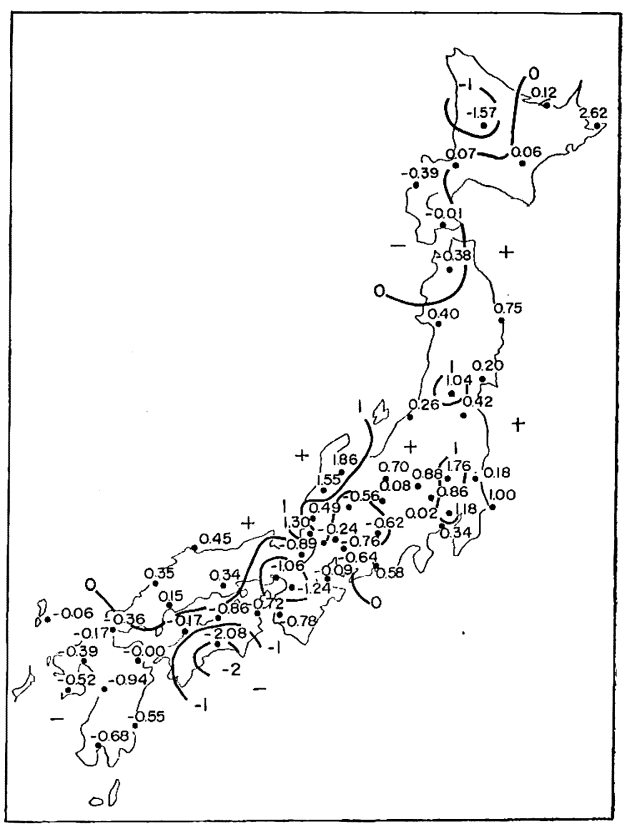

(j) 


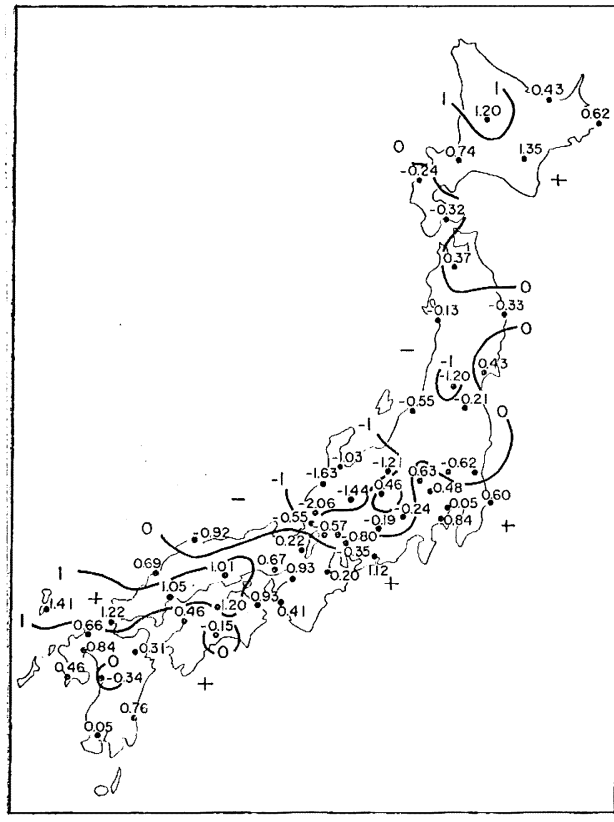

(k)

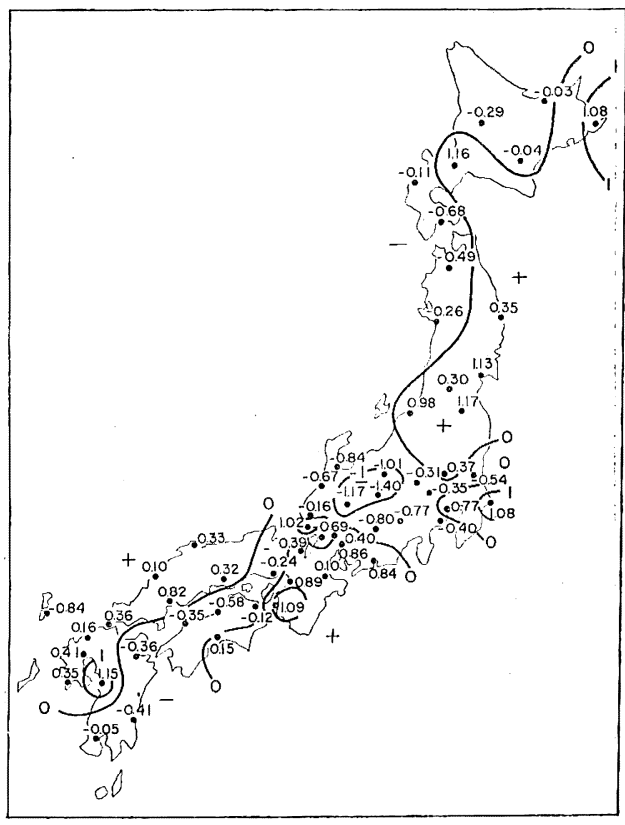

(1)

Fig. 4. Geographical distribution of trend index $I_{T}$ for each month.
(a) January
(b) February
(c) March
(d) April
(e) May
(f) June
(g) July
(h) August
(i) September
(i) October
(k) November
(1) December

increasing and decreasing trends seen in annual rainfall data as follows:

(i) The significant increasing trend of annual rainfall amounts appearing in the greater part of Hokkaido will be due to the monthly significant increasing trend of snowfall data caused by the monsoon in January and February since the other months have no significant trend at Hokkaidō, and Hokkaido district has negative persistency on its Japan Sea side in January, and show as very large fluctuation arround the mean value as is seen in the values of M.D. (y) and A.D. (y) of Fig. 24 presented in the author's previous paper (1967).

(ii) The significant increasing trend of annual rainfall amount seen in the western part of the Hokuriku district will be mainly due to the conspicuous increasing trend of monthly snowfall caused by the winter monsoon and secondly to the gradually increasing trend of monthly rainfall caused by Bai-u (June) and by typhoons and Shūrin (September and October), moreover secular variation of monthly rainfall amounts has the most apparent variability and no persistency in January as is shown in Fig. 24 (f) presented in the author's previous paper (1967).

(iii) The significant increasing trend of annual rainfall amount seen over the western and the central Kyūshū district will be mainly due to rainfall increasing caused by typhoon in September, and secondly to the significant increasing tendency in February, since no stable persistency and variability is seen in the other 
Table 3. Several regions having significant increasing and decreasing trends for every month.

\begin{tabular}{|c|c|c|}
\hline Month & Increasing region & Decreasing region \\
\hline January & Hokkaidō, Tōhoku, Hokuriku & West and Central part of Japan \\
\hline February & Greater part of Japan & Kantō, Southern part of Holkkaidō \\
\hline March & Hokkaidō and Hokuriku & Greater part of Japan \\
\hline April & Hokkaidō, Tōhoku, Kantō and Kinki & $\begin{array}{l}\text { West Japan, Central inner part of } \\
\text { Japan }\end{array}$ \\
\hline May & Japan Sea side, West Japan & East Pacific Ocean side of Japan \\
\hline June & Greater part of Japan & A part of Hokkaidō and Kyushū \\
\hline July & Japan Sea side of Japan, West Japan & Inner mountain range of Japan \\
\hline August & $\begin{array}{l}\text { Hokkaidō, West Pacific Ocean side of } \\
\text { Japan }\end{array}$ & Tōhoku, Northern part of Kantō \\
\hline September & Japan Sea side of Japan, Hokkaidō & $\begin{array}{l}\text { Pacific Ocean side of Japan, Inner } \\
\text { central part of Japan }\end{array}$ \\
\hline October & $\begin{array}{l}\text { Tōhoku, Hokuriku, Kantō and } \\
\text { Chūgoku }\end{array}$ & A part of Hokkaido,, South-West Japan \\
\hline November & $\begin{array}{l}\text { Pacific Ocean side of Japan, West } \\
\text { Japan }\end{array}$ & $\begin{array}{l}\text { Tōhoku, Hokuriku and a part of } \\
\text { Chūbu }\end{array}$ \\
\hline December & $\begin{array}{l}\text { West Japan Sea side, Kinki and } \\
\text { Töhoku }\end{array}$ & $\begin{array}{l}\text { Central mountain range of Japan, A } \\
\text { part of Kyushū and Shikok } u\end{array}$ \\
\hline
\end{tabular}

months.

(iv) The significant decreasing trend of annual rainfall amounts seen over the southern part of the Chūbu district and the Tökai district may be due to snowfall decreasing in January and to the significant decreasing tendency of monthly rainfall amounts in March. Moreover, persistency can hardly be noticed and variability is quite large in January in these districts.

(v) The significant decreasing trend of annual rainfall amounts seen over the northern Kantō ${ }_{\text {district }}$ and the Pacific Ocean side of the Töhoku district may probably be due to the gradually decreasing though not significant tendency of monthly rainfall amounts in January, March, May and July mainly, and the significant decreasing trend of monthly rainfall amounts in September caused by typhoons and Bai-u. Variability and persistency are so small that they can not be seen, and in August variability is larger in the Kantō district than the Pacific Ocean side of the Töhoku district in Japan. In these itemized descriptions, the trend characters of monthly rainfall are verified by addition of variability and persistency seen in the secular variations of monthly rainfall amounts in connection with the significant trend of annual rainfall amounts.

T. YAmamoto (1958). found the following three types of secular tendencies of rainfall amounts in summer season (from May to September) through his synthetic 
graphical comparisons of secular changes in Japan:

A type: The northern and the central part of Japan (for example, Gifu) $\cdots$ Decreasing trend.

B type: The northern part of Hokkaido district-No increasing or decreasing trend.

C type: Formosa and Okinawa districts...Increasing trend.

In this type classification, the whole domain of Japan is not covered in a mutually exclusive and exhaustive form. Fully aware of this deficiency, the author will try a comparison between his results with the above.

$(\alpha)$ The northern and the central part of Japan-According to the author's analysis due to the trend index $I_{T}$, no significant region is noticed in May and June, but decreasing trends are noticed in the several districts rather in July, while a not-significant increasing trend is seen in August and again in September significant decreasing trends appear almost everywhere and are likely to offset the not-significant increasing trend of the previous month.

After all, a conclusion which is practically the same as T. YAMAMOTO's is deduced generally as the summarized outline over May, June, July, August and September. In other words, T. YAMAMOTO's conclusions are refined and confirmed by the author's analysis.

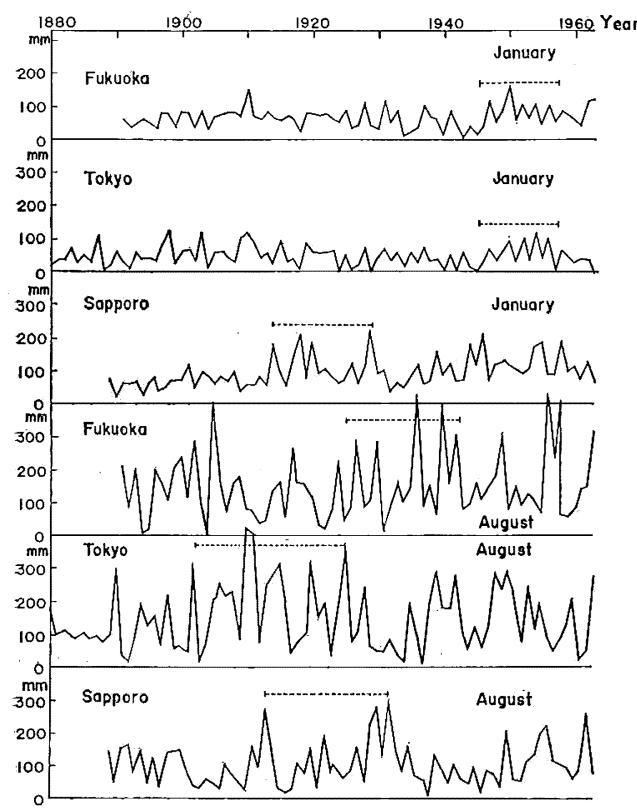

Fig. 5 (a). Secular fluctuations of monthly rainfall amounts in January and August at the representative points. (1880-1963)

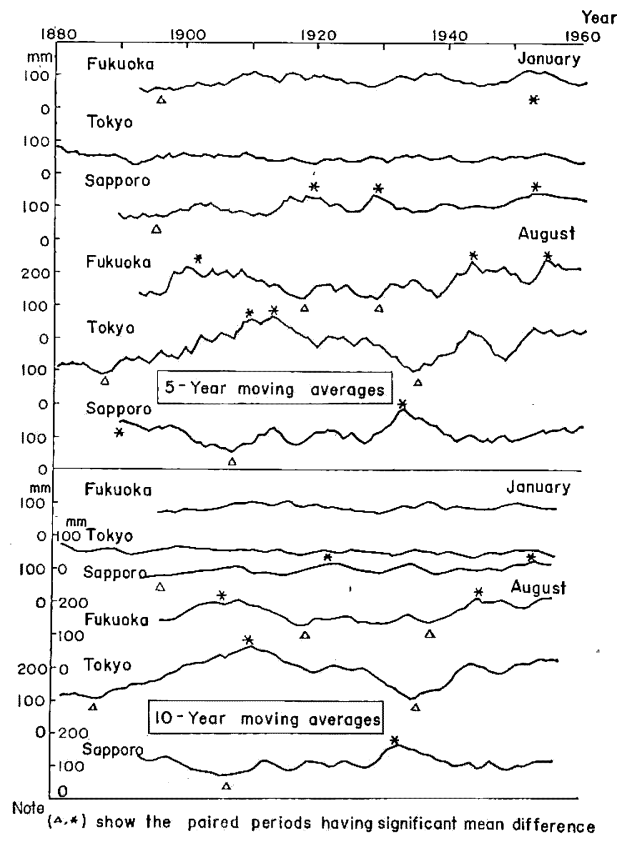

Fig. 5 (b). Fluctuations of the 5-year and 10-year moving averages in January and August. 
( $\beta$ ) The northern part of the Hokkaido district-As is seen in geographical distributions of trend indice $I_{T}$ during May and September, not-significant decreasing and increasing regions are mixed together in a complicated form, so that a similar conclusion to T. YAMAMOTO's is well recognized for each month during May and September.

(r) The Formosa and Okinawa districts-These districts are beyond the range of this study, and no comparative description is attempted here.

T. YAMAMOTO's study on the whole data obtained before 1950 at about fifteen observation points in Japan, while the author used all the possible data obtained before 1963 at 56 observation points of Japan for every month (from January to December). Consequently, the author's results are reasonably considered more precise and reliable on the whole.

Next, to bring out the actual secular variation patterns of monthly rainfall amounts, the author showed the several representative examples at Sapporo, Fukuoka and Tokyo in January and August in Fig. 5, where the period of the most conspicuous change period within ten successive years is indicated by a dotted line. Moreover, the symbols $\Delta$ and $*$, respectively, show the significantly different pairs of periods for five year mean and ten-year mean in this figure.
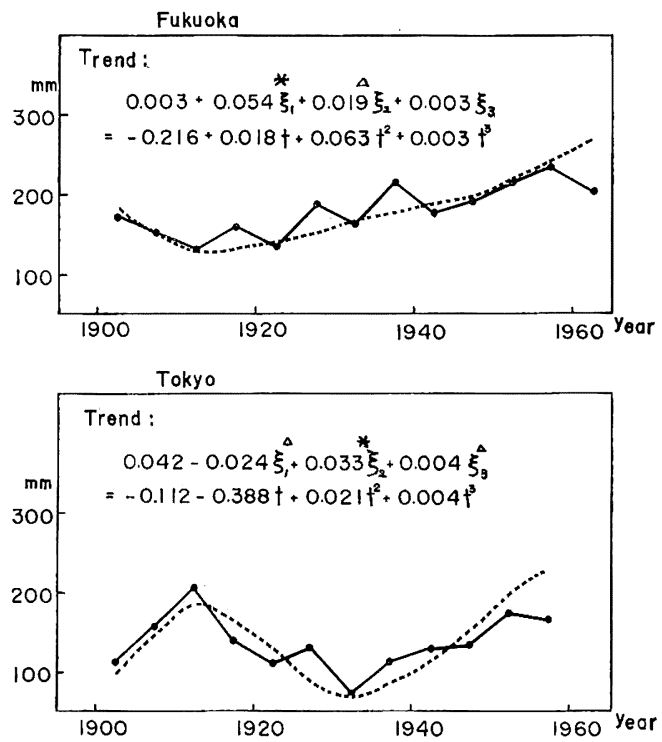

Note :

Solid and dotted lines show actual values and flited

curves respectively. (Origin: 1930)

$\triangle$ and show the significant coefficients at the level of

$20 \%$ and $5 \%$ respectively, (occording to normal regression theory)

Fig. 6. Actual mean values for five years (full lines) and the polynomial trend curves (broken lines) of the third order for monthly rainfall amounts in August. (1900-1963) 
Based on these simple comparisons, fitting of orthogonal polynomials was performed to the whole period that seemed to have any significant curvilinear trend; and transformation (2.6) was numerically given as was shown in Fig. 6, where the symbols $\Delta$ and $*$ denoted the significant coefficients ascertained at $10 \%$ and $5 \%$ levels on the relation (2.5), respectively.

As in the treatment of annual rainfall amounts, the results supplement suggestive informations for the various analyse due to trend index $I_{T}$.

In any case, Tokyo and Fukuoka have different curvilinear increasing trends, even though they have the same significant trend in trend index $I_{T}$. For example the former has a cubic curve type and the latter a quadratic curve type as was shown in Fig. 6.

It will be desirable that such a detailed analysis based on polynomial fitting be performed for all the stations over every month, but this is apparently impossible for any one man. Only some examples are therefore shown in this section.

\section{Secular variation in the rainfall amounts caused by Bai-u}

The rainfall caused annually by Bai-u or typhoon is rather important from a climatological point of view, generally occupying about fifty percent of the total annual amount. The author (1957) confirmed this fact at about twenty observation points in 1953, by categorically classified summation of daily rainfall amounts for nine causes, and moreover I. MORI (1959) reported a similar result for other years to the author.

Needless to say, rainfall amounts caused by Bai-u or typhoons are different for different regions and the above-stated fifty percent is an averaged amount over whole Japan.

Generally, the total rainfall amount of June and July is comparatively large in western Japan and rather less in northern Japan, and its ratio to annual rainfall amounts usually appear in averaged values within the range 15\%-30\% in Japan.

Therefore, in order to study the secular variation of rainfall amounts caused by Bai- $u$, the determination rule of the Bai- $u$ period must be clarified in relation to the past several studies.

K. SAKATA (1952) and K. TAKAHASHI (1953) performed independently climatic seasonal classification and arrived at similar results in Japan. According to their studies the next statistical specification will be suitable for us to determine the Bai-u period:

beginning day of Bai-u-the 8th day ( \pm five days) in June.

ending day of Bai-u-the 13th day (土six days) in July.

From climatological viewpoint, Bai-u starts earlier in southern Japan than in northern Japan and the Bai-u period is considered somewhat longer than that of the oriental calendar as is shown in "Climate of Japan" (1958) p. 59.

For example, the Bai-u period had the range between the 3rd day of June and the 24th day of July in 1953 according to the "Meteorological Review" (published by 
CMO). On the other hand, M. Yoshino (1965) pointed out four stages of Bai-u from the end of May to the middle decade of July, and the different types of Bai-u year by year.

The local heavy rainfall of Bai-u often appears in the middle of July, so T. MizUno (1958) considers July a rainy month of the Bai-u type.

From a synthetic consideration of the past studies mentioned above, the author considered the total rainfall amount of June and July as the rainfall amounts caused by Bai-u, and gave the representative examples of secular variations in Fig. 7 .

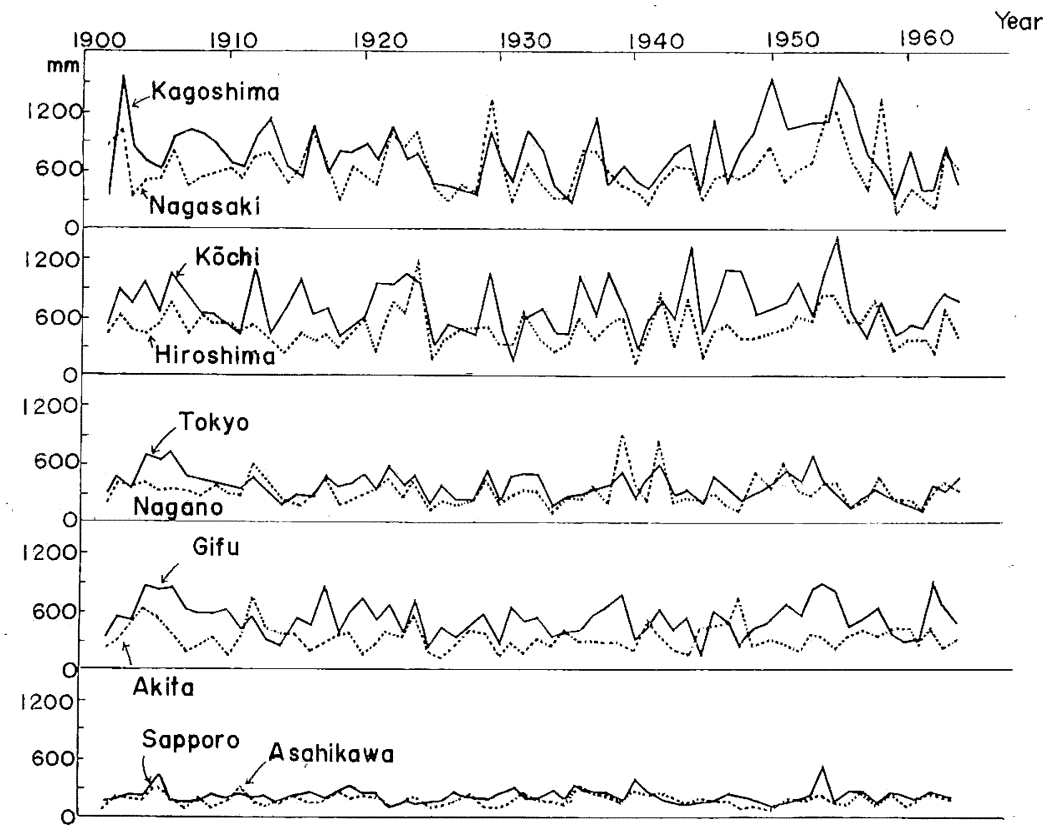

Fig. 7. Secular fluctuations of rainfall data caused mainly by Bai-u at representative points. (1900-1963)

On the other hand, an example of geographical distribution was prepared for actual rainfall amounts caused by Bai-u in 1953 by Fig. 8. In this case the total number of days within the Bai-u period is about 52 as was previously indicated, and differences between actual rainfall amounts caused by Bai-u and the total rainfall amount of June and July are sufficiently small in comparison with the latter amount.

The geographical distribution of trend index $I_{T}$ is shown in Fig. 9 for the total rainfall amount of June and July, and then the author should like to point out three reasons why this geographical feature is considered as invariant for small modifications of the Bai-u period.

(a) The total rainfall amount of June and July is generally considered as a little larger than the exact rainfall amount caused by Bai-u, but the secular relative variation tendency itself will be almost unchanged even if the base line of variation 


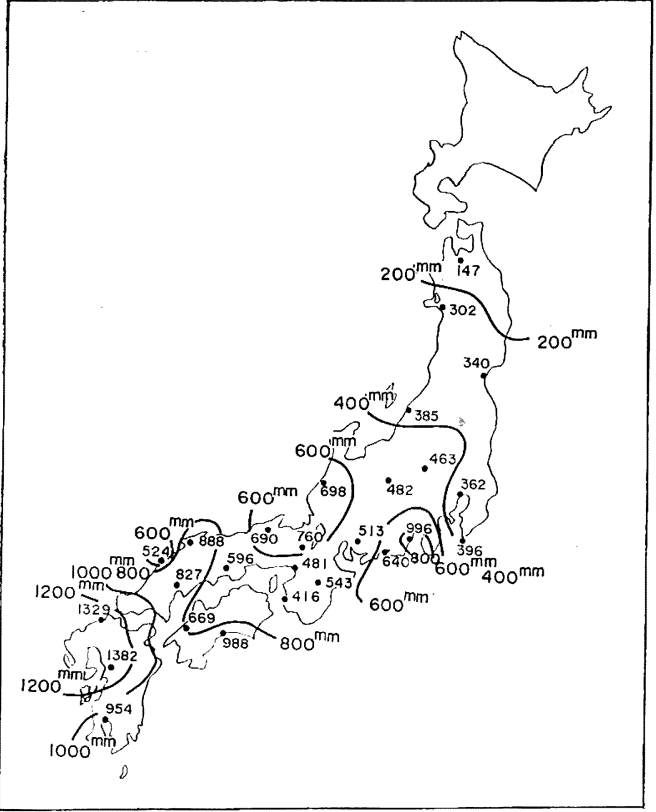

Fig. 8. Geographical distribution of total rainfall amounts caused by Bai-u (1953).

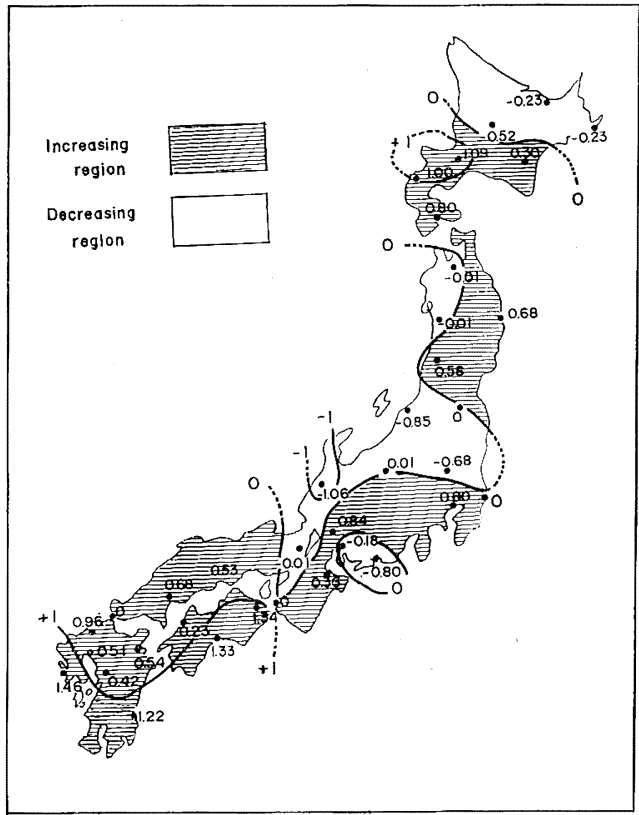

Fig. 9. Geographical distribution of trend index $I_{T}$ for annual rainfall amounts caused mainly by Bai-u.

is systematically biased by changing the Bai-u period, so the trend index will also be unchanged.

(b) In the first decade of June, rainy or cloudy days generally appear somewhat frequently in Japan, and the rainfall amount of this decade is taken into account in the author's assumption of rainfall caused by Bai-u. On the contrary, the last part of July generally has clear days, so the rainfall amount of this period is considered negligible compared to the large rainfall amount caused by Bai-u.

(c) The computation of $I_{T}$ apparently depends on the ranking of rainfall amount only, so a small modification of Bai-u period is not considered to affect the computation of $I_{T}$.

Now, trend indices $I_{T}$ appear within the range $(+1--1)$ over the greater part of Japan and the significant or decreasing trend is rather obscure, as is seen in Fig. 9 , but significant increasing trends are noticed parts of Japan; i.e. on the Pacific Ocean side of the Kyushū and Shikoku districts and the Japan Sea side of Hokkaidō.

And not-significant increasing trends cover the western part of Japan though conspicuous geographical characters hardly be seen in the distribution of $I_{T}$, since local heavy rainfall phenomena often appear in these districts recently.

\section{Secular variation in the rainfall amounts caused by typoons}

The rainfall amount caused by typhoons is an important part of the annual total 
rainfall amount, as was mentioned in the previous section.

So in this section, the secular variations of rainfall amounts caused by typhoons are systematically verified, but in the first place, the method of determining the rainfall amount caused by typhoons accurately must be established in connection with the accuracy of the synoptic weather map.

As is well known to us, the synoptic weather map has regularly been made since the year 1902 in Japan, but the observation network was not extensive enough to catch typhoon in its initial stage. I. MORI (1959) computed rainfall amounts caused by typhoos from 1912 and 1955 for twelve representative points in Japan, and the author (1957) computed the same from 1924 to 1954 for eighteen points in Japan, and obtained the analysis result based on trend index $I_{T}$.

These two studies slightly differ from one another in the data used, since the present author took into account the following:

Rain caused by the activities of a front accompanying the approach of a typhoon near Japan.

Rain caused by a front extending south from the center of a deformed cyclone.

So, generally the author's summation results are systematically larger than those of I. MORI when compared year for year and point for point, but these differences hardly influenced the discussion of secular variations because the correlation coefficients between these two different original data exist actually within the range 0.940.99 .

Then, the author supplemented the above results with the recent data (1955-1964) and recomputed the trend index $I_{T}$ for each point appearing in either of the above two studies, by using of rainfall amounts caused by typhoon over the whole period 1924-1964.

For the following three reasons the year 1924 was made the starting year for investigating the secular variation of rainfall amounts caused by typhoons.

(a) The observation network was pretty well established in the southern sea domain from about this year, so that typhoons came to be clearly caught in the synoptic weather map.

(b) Meteorological and climatological knowledge concerning the typhoon, cyclone and front made rapid strides from about 1924 and these came into the synoptic weather map regularly.

For example, the front theory of J. BJERKNES appeared in 1919, the wave theory of the cyclone due to the Norway school was proposed in 1920 and 1921, and the 1st volume of the Second series of Journal of Meteorological Society of Japan was firstly published in 1924 .

(c) In the formidable report

The Collected Data of Typhoons in Japan: published by the River Department of the Construction Ministry in Japan (1949),

the data of typhoons are summarized since the year 1924, and this report has been quite useful for the author. 
Table 4. Total amounts of rainfall caused by typhoons and tropical cyclones in Japan.

\begin{tabular}{|c|c|c|c|c|c|c|c|c|c|c|c|c|}
\hline $\begin{array}{r}\text { Station } \\
\text { Year } \\
\text { No. }\end{array}$ & 1 & 2 & 3 & 4 & 5 & 6 & 7 & 8 & 9 & 10 & 11 & 12 \\
\hline 1924 & 337 & 227 & 369 & 331 & 299 & 383 & 175 & 254 & 307 & 89 & 259 & 364 \\
\hline 25 & 226 & 180 & 574 & 305 & 612 & 688 & 179 & 349 & 301 & 316 & 485 & 685 \\
\hline 26 & 85 & 58 & 144 & 62 & 128 & 131 & 129 & 53 & 87 & 107 & 112 & 148 \\
\hline 27 & 451 & 340 & 552 & 229 & 271 & 353 & 68 & 194 & 323 & 208 & 219 & 416 \\
\hline 28 & 186 & 141 & 210 & 66 & 666 & 581 & 104 & 207 & 176 & 243 & 339 & 438 \\
\hline 29 & 482 & 256 & 343 & 95 & 624 & 634 & 150 & 189 & 164 & 431 & 611 & 777 \\
\hline 1930 & 408 & 218 & 316 & 204 & 148 & 116 & 65 & 249 & 213 & 66 & 167 & 109 \\
\hline 31 & 191 & 129 & 224 & 103 & 357 & 420 & 113 & 167 & 131 & 106 & 120 & 291 \\
\hline 32 & 33 & 107 & 318 & 23 & 243 & 32 & 20 & 139 & 169 & 84 & 69 & 218 \\
\hline 33 & 256 & 260 & 271 & 187 & 350 & 420 & 174 & 176 & 233 & 218 & 124 & 191 \\
\hline 34 & 189 & 168 & 368 & 323 & 231 & 171 & 245 & 259 & 293 & 41 & 56 & 62 \\
\hline 35 & 312 & 215 & 88 & 708 & 393 & 1048 & 521 & 168 & 138 & 628 & 489 & 339 \\
\hline 36 & 403 & 264 & 389 & 106 & 290 & 373 & 45 & 115 & 174 & 89 & 232 & 167 \\
\hline 37 & 206 & 143 & 124 & 268 & 138 & 339 & 136 & 119 & 191 & 73 & 59 & 54 \\
\hline 38 & 212 & 72 & 189 & 70 & 227 & 116 & 212 & 54 & 60 & 225 & 263 & 749 \\
\hline 39 & 127 & 187 & 200 & 123 & 260 & 198 & 24 & 68 & 88 & 121 & 160 & 103 \\
\hline 1940 & 286 & 168 & 238 & 184 & 163 & 377 & 160 & 241 & 241 & 57 & 168 & 79 \\
\hline 41 & 224 & 299 & 226 & 585 & 524 & 467 & 252 & 220 & 155 & 212 & 259 & 448 \\
\hline 42 & 242 & 186 & 204 & 164 & 436 & 373 & 162 & 241 & 187 & 201 & 296 & 236 \\
\hline 43 & 749 & 445 & 538 & 345 & 459 & 878 & 629 & 807 & 386 & 187 & 199 & 374 \\
\hline 44 & 185 & 64 & 11 & 220 & 173 & 170 & 252 & 151 & 123 & 249 & 199 & 227 \\
\hline 45 & 451 & 310 & 352 & 513 & 931 & 583 & 491 & 558 & 516 & 266 & 473 & 433 \\
\hline 46 & 174 & 108 & 245 & 66 & 286 & 335 & 45 & 177 & 183 & 59 & 95 & 68 \\
\hline 47 & 212 & 361 & 211 & 198 & 188 & 80 & 150 & 223 & 150 & 110 & 185 & 174 \\
\hline 48 & 2 & 214 & 301 & 20 & 249 & 70 & 72 & 312 & 271 & 47 & 160 & 367 \\
\hline 49 & 834 & 511 & 374 & 433 & 508 & 822 & 191 & 163 & 386 & 350 & 270 & 459 \\
\hline 1950 & 706 & 583 & 438 & 189 & 654 & 620 & 88 & 267 & 259 & 279 & 411 & 544 \\
\hline 51 & 289 & 135 & 218 & 297 & 331 & 652 & 163 & 243 & 224 & 128 & 179 & 268 \\
\hline 52 & 252 & 348 & 306 & 158 & 511 & 213 & 65 & 236 & 241 & 123 & 197 & 127 \\
\hline 53 & 35 & 183 & 156 & 6 & 407 & 227 & 79 & 287 & 227 & 238 & 220 & 56 \\
\hline 54 & 484 & 335 & 426 & 427 & 518 & 669 & 232 & 264 & 425 & 190 & 310 & 203 \\
\hline 55 & 466 & 253 & 210 & 247 & 330 & 411 & 120 & 213 & 163 & 163 & 213 & 263 \\
\hline 56 & 196 & 256 & 267 & 188 & 287 & 610 & 92 & 132 & 126 & 203 & 148 & 118 \\
\hline 57 & 347 & 119 & 250 & 202 & 305 & 698 & 141 & 230 & 117 & 436 & 300 & 274 \\
\hline 58 & 114 & 133 & 111 & 102 & 504 & 343 & 183 & 79 & 120 & 259 & 379 & 784 \\
\hline 59 & 502 & 381 & 337 & 228 & 599 & 620 & 213 & 264 & 86 & 412 & 537 & 422 \\
\hline 1960 & 333 & 204 & 240 & 194 & 481 & 398 & 180 & 204 & 457 & 317 & 334 & 310 \\
\hline 61 & 477 & 297 & 238 & 353 & 779 & 700 & 165 & 161 & 300 & 513 & 517 & 291 \\
\hline 62 & 572 & 466 & 430 & 243 & 189 & 265 & 269 & 185 & 213 & 131 & 257 & 222 \\
\hline 63 & 371 & 400 & 272 & 283 & 696 & 851 & 433 & 358 & 339 & 344 & 289 & 569 \\
\hline 64 & 280 & 41 & 28 & 66 & 181 & 210 & 67 & 60 & 43 & 84 & 134 & 162 \\
\hline
\end{tabular}

Remark: (I) Place name of each station number
1. Kagoshima 2. Kumamoto
3. Nagasaki
4. Fukuoka
5. Tokushima
6. Köchi

7. Hamada

8. Hiroshima

9. Shimonoseki 10. Ōsaka

11. Nagoya

12. Tokyo 


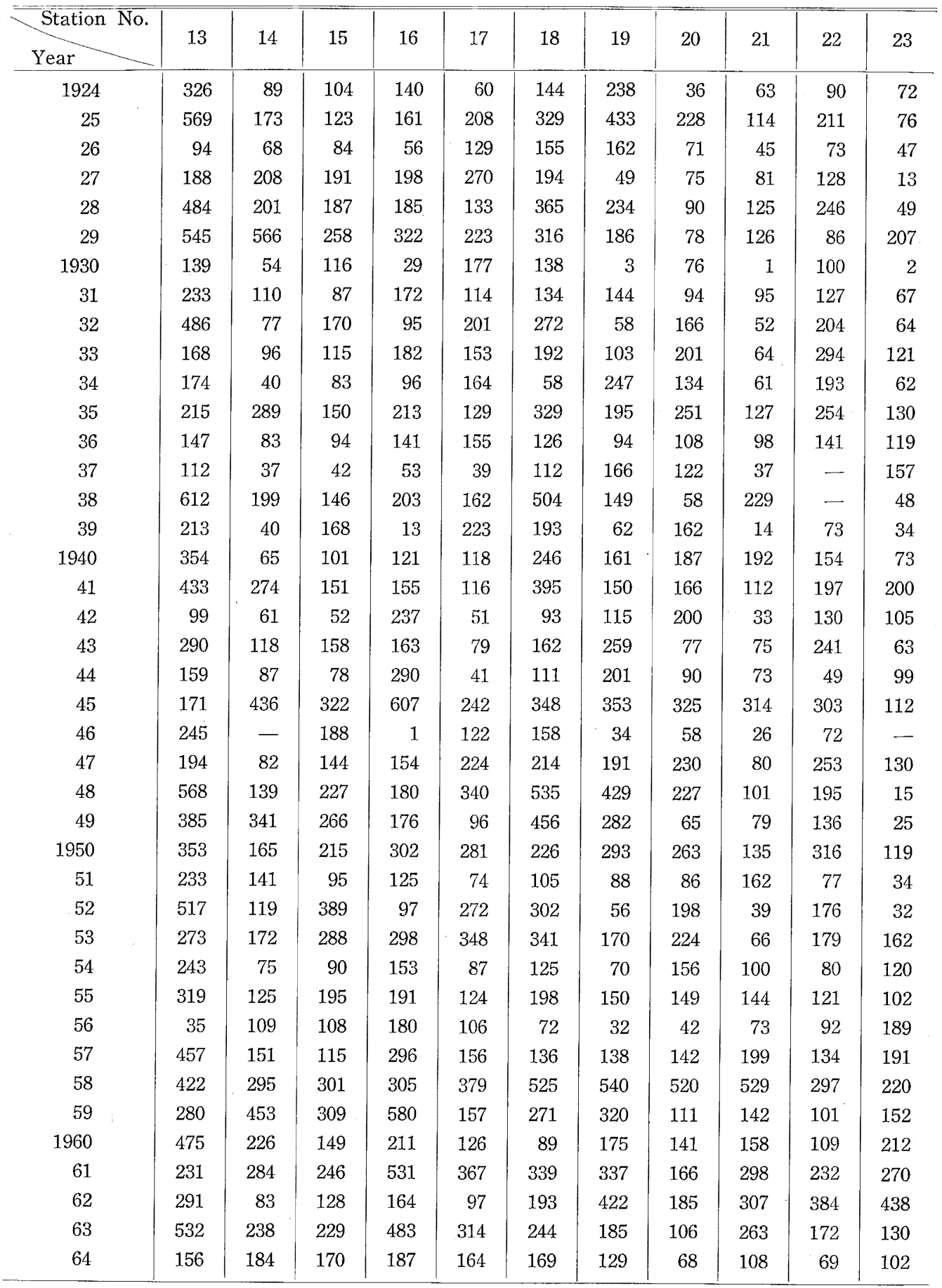

13. Chōshi 14. Matsumoto 15. Nagano 16. Kanazawa 17. Niigata 18. Fukushima

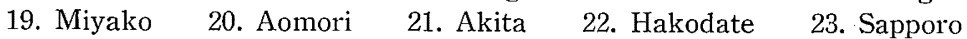
(II) Unit : $\mathrm{mm}$ 
In order to maintain the essential homogeneity of data, the author would like to take up 1924, as the starting point in this section, but it must be admitted that this is at any rate for the sake of convenience.

In Table 4 are shown the summarized results of rainfall amounts caused by typhoons during the period 1924-1964, for the twenty-three representative points of Japan.

This number is not considered as large enough for describing the general geographical character. However, it is beyond the competence of one man to incease the number of observation points further, since the daily weather map must be treated exactly for each station year by year over the long period (1924-1964). These twentythree points may be considered almost satisfactory in representing the outline of the geographical features, seeing that one or two points are allocated at least to each of the regions classified by the rainfall character already in the author's paper (1967).

The geographical distribution of trend index $I_{T}$ is given by Fig. 10 for such rainfall amounts caused mainly by typhoons in Japan, and the following geographical characters can be pointed out:

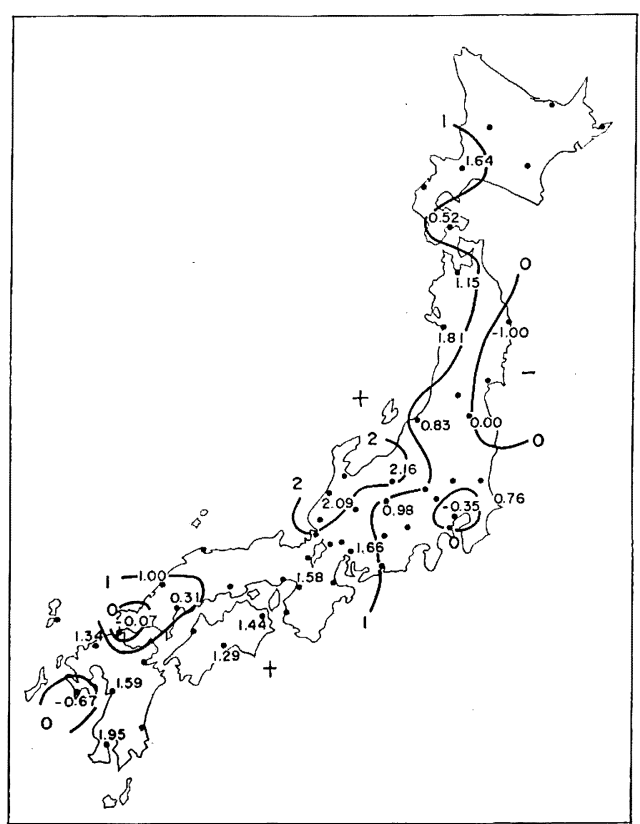

Fig. 10. Geographical distribution of trend index $I_{T}$ for annual rainfall amounts caused mainly by typhoons. (19241964)

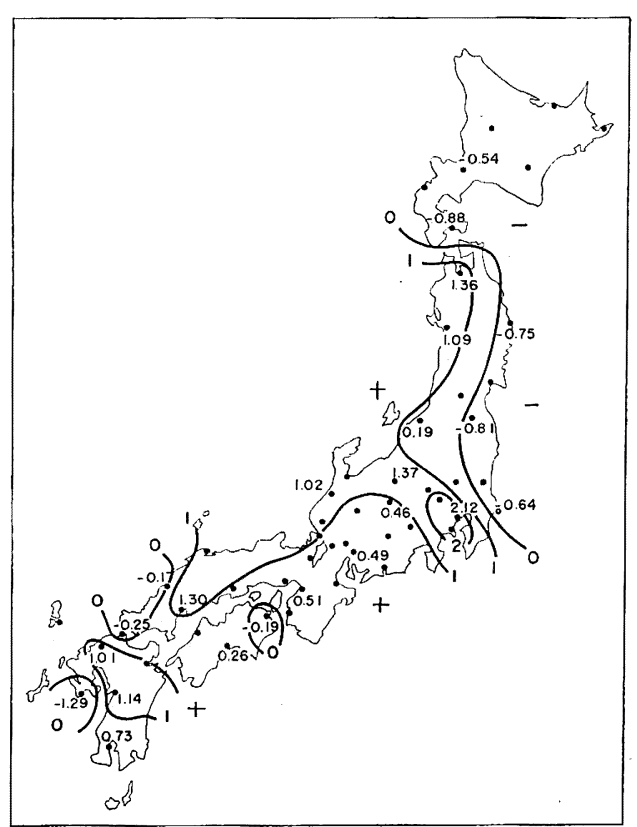

Fig. 11. Geographical distribution of trend index $I_{T}$ for annual rainfall amounts caused by typhoons excluding June and July. (1924-1964)

(i) Trend index $I_{T}$ is generally positive over the whole of Japan, except at four points (Tokyo, Miyako, Shimonoseki and Nagasaki), and particularly, significant increasing trends are seen at a part of western Japan and the Hokuriku district.

(ii) The number of points having a not-significant increasing trends is rather numerous in eastern Japan. 
But the rainfall amount in June and July caused by typhoons certainly assumed as a part of rainfall amount due to Bai-u in the previous section, so this conventional classification may be doubtful.

Hereafter, the rainfall amounts caused by typhoons are again computed except for June and July for each point and trend index $I_{T}$ is also computed by use of such rearranged secular variation. The geographical distribution of such corrected index $I_{T}$ is shown in Fig. 11 in the same way as in Fig. 10.

Both Fig. 10 and Fig. 11 have analogous geographical features but have several differences in details. For example, the value of $I_{T}$ at Tokyo is negative in Fig. 10 while conspicuously positive in Fig. 11 and in reverse, the Hokuriku district has a significant increasing trend in Fig. 10, but not in Fig. 11.

The fitting of polynomial and statistical analysis to compute variability and persistency indices is omitted in this section because it is considered unnecessary (significant trend is not so clear over the whole of Japan).

\section{Synthetic considerations of the climatic change of rainfall and designs planning}

In the four sections preceding this, the various geographical characters in the secular variation of rainfall amounts have been treated rather individually, and now a synthetic description will be desirable, even though the geographical features are quite complicated as were shown above.

The following results can be pointed out in summary after a synthetic consideration of the numerous figures concerning trend analysis mentioned in the previous sections :

(a) In the geographical distribution of trend index $I_{T}$, the not-significant trend regions is somewhat more widely spread over Japan than the significant trend regions except for the secular variation rainfall amounts caused by Bai-u.

(b) Both annual and monthly rainfall amouts have no remarkable persistency as a rule, and secular variability is comparatively large in the southwestern part and smaller in the northeastern part of Japan. Moreover, such variability is a little large on the Japan Sea side than on the Pacific Ocean side of Japan and is least in Hokkaidō.

(c) A general significant increasing tendency is apparent over the Kyūshū, San-in and the western part of the Hokuriku district year by year in Japan, but the cause of this tendency is locally different.

Nevertheless, the increasing type is the very large up-and-down fluctuation form arround the normal mean value, which is common to the three districts above.

The significant increasing tendency appearing in Hokkaido is clearly different from that of the other districts as was pointed out by T. SEKIGUCHI (1964).

(d) The general significant decreasing tendency is apparent over the Pacific Ocean side of the Töhoku district, the northern Kanto district, the inner mountain range and the southern part of the Chübu district and Tōkai district.

As the climatic cause of such a trend, the author would like to indicate the fact that the number of cyclones and fronts that move north eastward along the Pacific 
Ocean side of Japan has relatively and gradually decreased year by year. This is responsible for the recent narrowing of the region suitable for skiing, but this tendency is not seen over the whole of Japan since an increasing tendency in snowfall is seen at the Hokuriku and San-in districts.

(e) Secular variation of the rainfall amounts are very complicated in every district of Japan, but roughly speaking, the tri-partite division into the Japan Sea side, the Pacific Ocean side and Hokkaido as proposed by T. SEKIGUCHI (1964) holds quite well, even though a few local anomalies are inevitable within each region.

Lastly, the author would like to point out the possible causes of the increasing or decreasing trend described above in this section.

A hypothetical explanation was proposed that the increasing tendency of annual mean temperature (its rate being about $1 \sim 2^{\circ} \mathrm{C}$ per 100 year at a large city and about $0.5 \sim 1.5^{\circ} \mathrm{C}$ per 100 year at the other regions in Japan) might be partly responsible for rainfall increasing, but this relation is so complicated since rainfall has a stronger locality than temperature, being apt to be affected by orographic conditions. The author therefore considers the synchronous relation as douftfull.

Large-scale variation of the zonal index type pointed out by H.C. WILLETT will gave some suggestion as to secular change of rainfall, but no physical explanation of it which is convincingly clear has not yet been given. After all, the causes of secular variation is remained to be cleared up.

Nevertheless, prediction or extrapolation of secular variation is often urgently in climatological studies, so statistical inferences are to be performed by application of the time series analysis such as M. OGAWARA and his collaborators (1954): tried to do it for monthly rainfall amounts. The statistical extrapolation procedure of the secular trend itself is not yet established firmly enough to serve for actual purpose, even through the idea of the stochastic trend was recently proposed by M.H. QUENOUILLE etc.

In order to plan the feature utilization of untouched water resources, some operational foundations or safety prediction with a high reliability must be established statistically. A simple but suggestive proposal will be given as a final note in the following:

Suppose the operational planning during the future $m$ years is desired from social activities under the past secular rainfall amounts with sample size $\mathrm{N}$ ( $\mathrm{N}$ years is the whole length of the observation period)

\section{Planning based on extreme value (maximum or minimum)}

We can discuss only the maximum value without loss of generality, since the essential consideration is completely the same as for the minimum value.

Let the ordered annual sample of size $\mathrm{N}$ be

$$
x_{1} \leqq x_{2} \leqq x_{3} \leqq \cdots \leqq x_{N-1} \leqq x_{N}
$$

and let $x_{(m)}$ be an unknown maximum value in a future $m$ year, then the probability $P\left(x_{(m)}>x_{N}\right)$ is equal to $m /(N+m)$ independently of the original frequency distribution, 
so this probability is certainly suggestive to feature planning. Next, the author obtained the following relation by a slight deformation of the well known inequality derived by Tschebyscheff.

$$
P\left\{X \geqq l X_{N}\right\} \leqq 1 / 2\left\{\left(l x_{N}-\bar{x}\right) / s\right\}^{2}
$$

where $\bar{x}$ and $s$ are the men value and the standard deviation computed from the past sample with size $N$ respectively. The relation (7.1) has the following sense.

"Suppose the case that $\bar{x}=100 \mathrm{~mm}, s=20 \mathrm{~mm}, x_{N}=300 \mathrm{~mm}, l=1.5$ or 2 and $N=60$, then we can say that the new maximum record exceeding twice the past maximum $300 \mathrm{~mm}$ will occur once during the sufficiently long period of 1350 years, and similarly that the new maximum record exceeding 1.5 times of the past maximum 300 $\mathrm{mm}$ will occur once during period of 600 year."

Further planning based on the relation (7.1) seems to be sufficiently safe but is accompanied with the following risk.

For example, an event occuring once in about 600 years might occured the next year or the year after next. Generally speaking, the bank of Osaka Bay was destroyed by the overflowing of the Yodo river and the inundation by sea water due to the approach of the Ione typhoon, and such typhoon approaches western Japan once in ten years, statistically, so that the authorities reconstructed the bank to resist a typhoon approaching once in ten years. Then the 2nd Muroto Typhoon attacked Ōsaka Bay after ten years just, but as it was somewhat stronger than Ione, its bank was again destroyed.

This is an example of complete but accidental accordance between plan and executional results. Therefore, to obtain a safety planning with high reliability, no occurrence of such an event durring successive future $m$ years is desirable as a rule, so we will use the probability that the new maximum record exceeding the $l$ times of the past maximum appears once in the successive future $m$ years expressed by

$$
P_{m},{ }_{n}(l)=1-\left[1-P\left\{X \geqq l X_{n}\right\}\right]^{m}
$$

This probability was theoretically discussed for several models by the author; it is equal to about $1 / 50$ in the case of

$$
P\left\{X \geqq l x_{n}\right\}=1 / 600, \quad m=10 .
$$

In other words, the design planning of this case has a reliability of $98 \%$.

What has been given here is only a part of the synthetic expository contributions proposed by the author recently.

\section{Summary}

The secular trends of annual, monthly and special climatic rainfall amounts were studied more in detail than ever over the whole domain of Japan by use of as much data as possible. Trend index $I_{T}$ and polynominal fitting were mainly used to clarify the several characteristics of secular variations. Quantitative comparisons were also carried out to find the locality of secular variation. The main results obtained were shown in the preceding section and they will be helpful for long range forecasting of climatic rainfall amounts. 
Several trials have hitherto been made by E. FUKUI, K. TAKAHASHI and others in Japan, but they were not always satisfactory in data and the number of observation points. In view of their deficiencies, the author tried to describe systematically the trend characters of rainfall in Japan. Even if the author's results in this paper might be more or less corrected by new data in future, they will furnish adequate basis for future studies of climatic change.

Acknowledgements - The author wishes to express his sincere gratitude to Professor E. FUKUI of Tokyo Educational University for his earnest advice and suggestions and to the other professors of the same University for their valuable comments.

The author also would like to express his hearty thanks to Mr. M. OKUTA of Met. Res. Inst. and to Assistant Professor M. YoshINo of Hōsei University for their friendly comments throughout this study. The author is greatly indebted to Miss OzAKI for her assistance in drafting and also to Mrs. TsunEOKA for typing the manuscript.

\section{References and Data}

ARAI, Y., 1955: Secular change of climate. Kishō Kenkyū Note (Met. Res. Note), 6, 134-144.

ARAKAWA, H., 1955: Kikō Hendō-ron (Theory of climatic variation). 82p. (published by Chijin Shokan).

, 1956: Fluctuation of rainfall in the past 100 years in the Far East. Kagaku (published by Iwanami Shoten), 26, 41.

BRooKs, C.E.P., 1919: The secular variation of rainfall. Quart. J. Roy. Met. Soc., 45, 233-245.

BRÜCKER, E., 1890: Klimaschwankungen zeit 1700. Geographische Abhandlungen, 4.

HANN, J., 1898: Über die Reduktion kürzer Reihen von Niederschlagsmessungen auf die langjührige Reihe einer Nachbarstation. Met. Z., 15, 121-133.

Hellman, G., 1908: Über die extremen Schawankungen der Regenfalles. Zeitschrift der Gessellschaft für Erdkund zu Berlin, 605-615.

IzUBuchi, S., 1965: On the secular change of rainfall during Bai-u season at Tokushima. Tenki, (Weather) 12, 334-336.

KöPpen, W., 1928: Die Schwankungen der jährliche Regenmenge. Met. Z., 45, 281-289.

MANLEY, G., 1944: Some recent contributions to the study of climatic change. Quart. J. Roy. Met. Soc., 70, 197-219.

MAURER, H., 1911: Zur Methodik der Untersuchungen über Schwankungen des Niederschlagsmengen. Met. Z., 28, 97-111.

Japan Meteological Agency., 1963: The maximum records and their ranking since observation begginning. Climatic Tables of Japan, No. 7. 466p.

MorI, I., 1959: Statistics of rainfalls caused by Bai-u and typhoon. J. Geophys. Res., 11, 11-16.

Ogawara, M., T. Ozawa, E. Suzuki, T. Fujita and K. Tomatsu, 1952: Climatic fluctuation and climatological statistics in Japan. J. Geophys. Res., 4, 641-524.

OTANI, T., 1934: The secular variation of Bai-u. J. Met. Soc. Jap., 11, 501-504.

SeKiguchi, T., 1964: Locality of secular fluctuation of rainfall in Japan. Geogr. Rev. Japan. 37, $217-225$.

Suzuki, E. and K. Tomatsu, 1955: A statistical study on the amount of precipitation (4th report). On the secular variation of annual and monthly precipitation at every point in Japan. J. Geophys. Res., 7, 498-506.

SuzuKI, E., 1957: A statistical study on the amount of precipitation (8). Secular tendency of annual precipitation caused by typhoon and Bai-u. J. Geophys. Res., 9, 189-194. , 1967 : A statistical and climatological study on the rainfall in Japan. Pap. Met. Geophys., $18,103-181$.

TAKAHASHI, K., 1956: Secular change of rainfall. Tenki (Weather), 3, 12-14. 
Thielebein, H., 1933: Reduktions faktoren zum Hellmannschen Schwankungs Quotienten. Annalen der Hydrographic und maritimen Meteologie, 61, 178-190.

WiLleTT, H.C., 1949: Long periodic fluctuation of the general circulation of the atmosphere. J. Met., 6, 34-50.

Yамамото, T., 1950: On the secular change of climate in Japan (1). Geophys. Mag., 21, 249-268.

- _ 1951: On the secular change of climate in Japan (2). Geophys. Mag., 22, 35-70.

__ 1958: On the mechanism of climatic change in Japan. Geophys. Mag., 28, 505-515.

YAZAWA, D., 1964: Climatic fluctuations and regional classifications in Japan. An address at the monthly lecture meeting held in January at the Meteorological Society of Japan. (Unpublished)

\title{
日本における降水量の永年変動
}

\author{
鈴 木 栄 一
}

日本に抺ける降水量の永年変動の状態をまず，年降水量について調べ，つぎに月別の降水量について解析 し, さらに年降水量のうち梅雨期雨量, 台風による雨量についてその変動状態を統計的に解析した。解析 の方法としては, 順位相関によるトレンド検出, 直交多項式拉よびそれを変換した通常の多項式のあては め, 変動状態を記述するいくつかの指数の計算の 3 つを採用し, 增加または減少の実態を明らかにし, 地 域的な比較を行なった。資料は1900年以前から観測のなされている本邦全気象官署の1964 年までの值であ る。

\section{主な結果をあげると}

（i）本邦全域としてみた場合，増加傾向になっている地点が多い。

（ii）とくに九州, 四国地方は顕著な増加傾向域となっているが，それは主として台風による雨量が増 加しているからである。

（iii）東北, 北陸地方では增加と減少の区域が入りみだれて存在し，とくに冬季降水量（降雪量）の明 らかな增加域が点在しているが全般的には減少している。

（iv）関東地方はどの月別の降水量にも減少傾向の場合が多く，それが年降水量の明膫な減少傾向とな ってあらわれている。

などである。

これまでの研究で定性的に知られていたことが数量的な結果として明らかにされ，資料補足によって若 干訂正された結論が得られた。 